\title{
DOES DIGITAL FINANCIAL INCLUSION MATTER FOR BANK RISK-TAKING? EVIDENCE FROM THE DUAL- BANKING SYSTEM
}

\author{
Hasanul Banna ${ }^{1}$ and Md Rabiul Alam² \\ ${ }^{1}$ UAC, Universiti Malaya, Malaysia, banna@um.edu.my/ bannaje@yahoo.com \\ ${ }^{2}$ Universiti Malaya, Malaysia, rabiulalam_84@yahoo.com
}

\begin{abstract}
This paper examines the nexus between digital financial inclusion (DFI) and levels of bank risk-taking, using a sample of 283 commercial banks (Islamic and conventional) from six countries over the period 2011 to 2019 and deploying panel-corrected standard errors, two-stage least squares-instrumental variables and dynamic panel two-step generalized method of moments estimators. The findings suggest that Islamic banks take more risks than their counterpart conventional banks. The empirical evidence also indicates that an increase in the DFI index score reduces the overall level of bank risktaking and increases that of banking stability for commercial and conventional banks compared to Islamic ones. A strong association between DFI and bank risk-taking suggests that DFI not only reduces the default risk, leverage risk and portfolio risk of banks, but also increases financial mobility in the sample countries. Consequently, an inclusive digitalised banking industry ensures sustainable economic growth, which is likely to help maintain financial sustainability in times of crisis such as the Covid-19 pandemic. Our results are shown to be robust by various robustness checks. The study contributes to both the Islamic and conventional banking, as well as the digital financial inclusion, literature. The findings of the study provide various policy implications for policymakers and standard-setters in the countries examined.
\end{abstract}

Keywords: Digital financial inclusion index, Dual-banking, Bank risk-taking, Covid-19. JEL Classification: E44; F65; G21; G28.

\author{
Article history: \\ Received : October 8, 2020 \\ Revised : February 3, 2021 \\ Accepted : March 8, 2021 \\ Available online : May 20, 2021
}

https://doi.org/10.21098/jimf.v7i2.1320 


\section{INTRODUCTION}

\subsection{Background}

Based on the banking literature and modern banking theory, it is evident that banking stability and performance appear to be subject to any crisis or uncertainty emerging from financial markets, the nature of borrowers, and the nature of depositors, with whom banking interaction is intrinsically intertwined (Sarmiento \& Galán, 2017). Such crisis situations or uncertainty are termed as bank risktaking behaviour, which indicates the capability of certain banks to endure risks during periods of uncertainty, with the risk-taking tendency depending on their corporate governance strategy, regulatory framework, and competition (Agoraki, Delis, \& Pasiouras, 2011; Anginer, Demirguc-Kunt, Huizinga, \& Ma, 2013; Wagner, 2010). Bank risk-taking behaviour determines various respects of banking stability. Therefore, to enhance the performance level and financial stability, banks are inclined to take more risks (Sarmiento \& Galán, 2017), which mostly depend on the nature of the financial market and the banking regulatory framework (Flannery, 2009; Hughes \& Mester, 2008). However, the abrupt slowdown of the financial market during and after the global financial crisis (GFC) of 2007-09 shook the global financial sector, especially the banking sector. To recover from the consequences of the GFC, the banking industry initiated many short- and longterm measures, such as financial inclusion (henceforth FI), which enhanced bank risk-taking tendencies and consequently ensured banking stability (Ahamed \& Mallick, 2019; Banna, Alam, Ahmad, \& Sari, 2020a). Appropriate implementation of FI in the banking sector helped it recover its losses and regain financial stability by enhancing the risk-taking resilience of the banking industry (Al-Smadi, 2018; Banna et al., 2020a; Van, Nguyen, \& Vo, 2020).

Besides FI, banks are in the process of implementing digital financial inclusion (DFI), thus benefitting from technological advancement. Before the current pandemic, application of DFI in the banking sector had been progressing gradually. However, the current Covid-19 pandemic has encouraged its fullyfledged application, since most countries have implemented lockdowns, quarantine, and social distancing measures to prevent the exponential spread of the virus (Atkeson, 2020; Banna, 2020a). All these measures prevent people from making physical transactions. Therefore, policymakers realised the urgent need for DFI. DFI is an extension of FI, allowing contactless transactions in a cashless or remote manner conducted through a smart phone or other electronic device connected to the internet. Through the application of DFI, both service providers and receivers gain advantages (Klapper, 2017). With regard to the current crisis, the Covid-19 pandemic has drastically impacted the financial sector, in particular the banking sector, and its nature is no less deadly than that of the GFC, hence it is obvious how banks' risk-taking tendency is influenced by DFI, which has also been an important topic in the literature.

\subsection{Objectives}

In the current crisis, banks are undertaking their functions through the execution of DFI, whose widespread application is hoped will maintain banking stability. To do this, banks need to extend their risk-taking behaviour, as failure to do so might 
have a negative impact on bank stability (Koetter, 2008; Malikov, Restrepo-Tobon, \& Kumbhakar, 2015). Therefore, this study aims to assess the association between DFI and bank risk-taking behaviour. It investigates the impact of DFI, since in the Covid-19 situation this has become the only means to operate banking affairs. Consequently, it is necessary to determine whether the application of DFI has a positive or negative impact on risk-taking behaviour. Determining such an impact will create awareness, which will help to gauge the level of risks banks should take to face any uncertainty.

Therefore, this study aims to empirically investigate the impact of DFI on bank risk-taking behaviour in the context of the dual banking system. In addition, it intends to determine whether DFI has more impact on conventional or Islamic banks in terms of their risk-taking behaviour. The study places relative importance on Islamic banks, since globally Islamic finance is experiencing a $15 \%$ to $20 \%$ growth rate per annum (Hancock, 2013), with the assets of Islamic banking in commercial banks in 2013 set to exceed USD 1.7 trillion (Ernst \& Young, 2013). Moreover, after the GFC, Islamic banks were more capable of regaining their financial stability compared to their conventional counterparts (Ahmed, Mohieldin, Verbeek, \& Aboulmagd, 2015; Banna et al., 2020a). Moreover, both conventional and Islamic banks are always in competition in terms of profit maximisation, strategy setting, and financial stability.

The study is expected to contribute to the literature in a number of ways. First, unlike previous studies, it empirically investigates the impact of DFI on bank risktaking tendencies by considering dual banking data. Second, it considers global banking data from countries that practise dual banking, since Covid-19 has affected the global banking sector and economy (Wójcik \& Ioannou, 2020). Therefore, the study will enrich the existing literature related to the dual banking system. Finally, to check for robustness, various types of econometric techniques are deployed to establish the association between DFI and bank risk-taking tendencies during and after the Covid-19 pandemic era.

The remainder of the paper is organised as follows. Section 2 comprises the literature review, which is followed by presentation of the data sources and methodology in Section 3. Section 4 discusses the results and analysis, with concluding remarks and policy recommendations made in Section 5.

\section{LITERATURE REVIEW}

\subsection{Background Theory}

Every aspect of human life is prone to risk-taking, so is an integral part of people's daily lives (Ale, 2009; Trimpop, 1994). Therefore, whatever decisions people make, they first consider the risks and threats that might subsequently occur (Yates, 1992). Similarly, institutions also tend to take risks for their betterment and success, though some consider it as a potential loss of money and safety (Yates, 1992). The theory of risk-taking behaviour goes back to Richard Cantillon and John Stuart Mill, and was later modified in 1890 by the prominent economist Alfred Marshal (Landstrom, 2007). The theory considers that institutions or entrepreneurs are inclined to take risks for their own sustainability. They should take risks at a level they can support. If they take intolerable risks, they may face ruin instead 
of progress or success. However, some institutions are willing to take a high level of risks and challenges, whereas others prefer to take moderate risks that they can tolerate, based on the various types of resources they possess. Therefore, the banking industry was prone to risk-taking in a heightened manner after the GFC as a survival measure to retain its sustainability (Beltratti \& Stulz, 2012; Shleifer \& Vishny, 2010). Risk-taking in the banking industry has been considered as an important element that determines banking production (Hughes, Mester, \& Moon, 2001). Moreover, banking efficiency is also associated with credit risk and capitalisation (Berger \& DeYoung, 1997; Naceur \& Omran, 2011). Many studies show that highly capitalised banks are more cost efficient (Altunbas, Carbo, Gardener, \& Molyneux, 2007; Fiordelisi, Marques-Ibanez, \& Molyneux, 2011) as they likely to take greater risks at moments of uncertainty, as was clearly evident after the GFC. This was because any kind of uncertainty reduces informational asymmetries, triggers more market competition, and leads banks to look for greater yields in more risky projects (Dell'Ariccia \& Marquez, 2006; Keeley, 1990).

As a result, during and after the GFC, banks were inclined to more risk-taking through inclusive financial products and services in the form of financial inclusion. However, nowadays FI has been replaced with DFI, which has made financial affairs easily accessible by the public. Easily accessible and affordable financial services provided by the financial sector have the capacity to reduce agency problems, as well as reducing the information asymmetries between creditors and debtors (Beck, Lin, \& Ma, 2014). Moreover, such types of inclusive finance are also capable of minimising the volatility of banking sector volatility, as they help banks collect more deposits from more clients, which ultimately increases the liquidity of the banking sector (Han \& Melecky, 2013) and hence reduces bank risk-taking tendencies. Through the expansion of financial services, banks reduce the volatility of return as they avoid more costly and risky money market funds (Kacperczyk \& Schnabl, 2013).

\subsection{Relevant Empirical Studies}

As both financial inclusion and digital financial inclusion are interlinked, providing reliable definitions of them will make the study more comprehensive. Both terms have been defined by various bodies in several contexts. The United Nations (2015, p. 1) defines financial inclusion as "access to a full suite of financial services, provided with quality, for everyone who can use financial services, thereby leading to an increase financial capability." The Consultative Group to Assist the Poor (CGAP) states that "financial inclusion means that households and businesses have access and can effectively use appropriate financial services. Such services must be provided responsibly and sustainably, in a well-regulated environment" (CGAP, 2014, p. 1). Together with the definitions of financial inclusion, those of DFI have also been made from different perspectives. The World Bank (2015, p. 1) defines DFI as "the deployment of the cost-saving digital means to reach currently financially excluded and underserved populations with a range of formal financial services suited to their needs that are responsibly delivered at a cost affordable to customers and sustainable for providers." In similar terms, CGAP (2015) also states that DFI is "digital access to, and the use of, formal financial services by 
the excluded and underserved population." Moreover, Manyika, Lund, Singer, White and Berry (2016, p. 4) explain that digital finance refers to "financial services delivered via mobile phones, the internet or cards".

Innovation in the field of technology has been a blessing for the world, and is transforming the global financial sector, especially the banking sector, with the move from cash-based to cashless transactions in the form of DFI. However, the global financial sector has been drastically affected by the Covid-19 pandemic, which has corroded the global economy. Due to the pandemic, the banking sector is facing liquidity pressure, which creates a liquidity crisis (Li, Strahan, \& Zhang, 2020) and in turn increases banks' non-performing loans and increases their risktaking (Wójcik \& Ioannou, 2020). Liquidity crises have a significant influence on bank risk taking. The study of Dahir Ahmed, Mahat Fauziah and Ali Noor Azman (2018), employing a sample of 57 banks from BRICS countries over the period 2006 to 2015, found that funding liquidity risk had a negative influence on bank risk-taking. As liquidity risk decreases, bank risk-taking tendencies increase, and vice versa. A country's policy framework, economic stability, and sound political environment encourage higher levels of bank risk-taking, which ultimately upholds credit market competition (Ashraf, 2017). Higher levels of risk-taking are likely to maximise banks' profits and augment bank efficiency, although the risktaking might be heterogeneous among banks in terms of their size and ownership (Sarmiento \& Galán, 2017). As banks in the current crisis are applying DFI in their transactions, the interlink between DFI and risk-taking tendency is the topic of the study. The previous research of Kammoun, Loukil, \& Loukil (2020) in the context of the MENA region shows that the application of Fintech (DFI) fosters economic performance and financial stability by efficiently handling any risks and threats in the region, even in times of unrest and political instability. Full application of DFI augments the profitability of the banking sector, which ensures banking stability and minimises bank risk-taking (Ozili, 2018). When bank risk is minimised, banks become financially stable. Using the data of 4168 banks from 28 EU countries over the period 2010-2017, the recent study of Danisman and Tarazi (2020) shows that wider and affordable inclusion of financial services has a great stabilising impact on the European banking industry. Their study also focuses on digital payment systems, through which deprived classes of people such as those in rural areas, and the young, unemployed, and uneducated, can be included in formal financial services, which helps EU banks attain financial stability by reducing their risks and threats.

By deploying the GMM approach, Van et al. (2020) recently conducted an empirical study using a sample of 3071 Asian banks and found that more financial inclusion by banks ensures greater bank resilience, as FI helps banks reduce costs, augment revenue, minimise risk and expand market share. In addition, interest rates also have an impact on bank risk-taking behaviour. Lower interest rates promote a higher level of risk-taking tendency (Delis \& Kouretas, 2011). Bank risktaking behaviour is also highly impacted by the diversification of shareholders. In the context of the European banking sector, the empirical study of García-Kuhnert, Marchica, \& Mura (2015) found that banks with investors from diversified sectors were prone to take more risks, resulting in financial stability and development. 
Furthermore, many studies have also investigated how bank risk-taking tendency is influenced by other factors. For example, risk-taking behaviour is influenced by financial liberalisation (Cubillas \& González, 2014); corporate control (Anderson \& Fraser, 2000); political institutions (Ashraf, 2017); the nature of financial crises (Black \& Hazelwood, 2013); and the type of national culture (Ashraf, Zheng, \& Arshad, 2016). Most of these studies have only employed proxies for credit risk, disregarding other significant risks such as liquidity crises, insolvency problems, and market crises, upon which banks' stability and efficiency also depend (Sarmiento \& Galán, 2017). Moreover, risk-taking behaviour is also influenced by Fintech or DFI; the recent study of Wang, Liu, and Luo (2020) found that the development of Fintech increases the risk-taking behaviour of the banking sector. Interestingly, they also find an inverted U-shaped association between Fintech development and bank risk-taking; although Fintech initially intensifies bank risk-taking, this starts to decrease with further development of it.

However, very few empirical studies have shown the impact of DFI on bank risk-taking behaviour. Hence, this study aims to investigate this issue in the Covid-19 pandemic era by employing dual banking data, with relatively more focus on the Islamic banking industry.

\section{METHODOLOGY}

The objective of the research is to examine the relationship between DFI and bank risk-taking in a dual banking system. It also aims to establish how this nexus could be a possible way forward for the banking industry in facing uncertainty during the post-Covid-19 era. The study also seeks to explore any possible differences in the nexus for Islamic banks. Therefore, utilising the available data, it is necessary to examine the DFI and bank risk-taking nexus before the Covid-19 pandemic. This section presents the data sources, the model development and the methods used in the study.

\subsection{Data}

Although many financial institutions provide various financial services to clients, this study only considers the banking sector (both Islamic and conventional banks). The reason for choosing the dual banking system is that the Islamic banking sector was considered to be the most sustainable sector during the GFC compared to its counterparts, and it made great contributions to the economic stability of various countries (Banna et al., 2020a) as it has nearly USD 1.56 trillion $^{1}$ in banking assets. As a consequence, launching Islamic windows in conventional banks is a rising trend. Moreover, keeping pace with the competing conventional banks, Islamic banks across the world are gradually introducing various types of digital financial services (DFS) (Banna et al., 2020a) to build a wider outreach. In addition, the current Covid-19 pandemic is quickly pushing the banking sector towards fullyfledged implementation of DFS in order to keep the economy stable.

1 Based on IFSB Stability Report 2019 
This study initially considers Bangladesh, Bahrain, Brunei Darussalam, Indonesia, Iran, Kuwait, Malaysia, Pakistan, Qatar, Saudi Arabia, Sudan, Turkey and the United Arab Emirates, as these countries hold approximately $95 \%{ }^{2}$ of total Islamic banking assets and also operate dual banking systems in which conventional and Islamic banks co-exist. However, due to DFI data unavailability, the final sample is restricted to six countries, namely Bangladesh, Indonesia, Malaysia, Pakistan, Qatar and Sudan, which serve as the main focus in examining the DFI-bank risk-taking nexus in the context of dual banking systems.

We first chose the annual data of 286 commercial banks, 213 conventional and 73 Islamic, from the above six countries. However, due to data unavailability and missing values, our final sample consisted of 283 commercial banks, of which 210 were conventional ones and 73 Islamic, with unbalanced panel data over the period 2011 to 2019. Our study considers this timeframe as DFI data is mostly available from 2011 from the World Bank and International Monetary Fund (IMF) databases. A breakdown of the sample size is shown in Table 1, in which it can be seen that Indonesia has the highest number of banks (40\%), followed by Bangladesh (20\%) and Malaysia (17\%).

Table 1.

List of Countries and Number of Banks

\begin{tabular}{lcccc}
\hline Country & $\begin{array}{c}\text { Number of banks } \\
\text { (Observations) }\end{array}$ & Sample (\%) & $\begin{array}{c}\text { Number of } \\
\text { conventional } \\
\text { banks }\end{array}$ & $\begin{array}{c}\text { Number of } \\
\text { Islamic banks }\end{array}$ \\
\hline Bangladesh & $56(416)$ & 19.79 & 47 & 9 \\
Indonesia & $113(815)$ & 39.93 & 102 & 11 \\
Malaysia & $48(369)$ & 16.96 & 29 & 19 \\
Pakistan & $33(254)$ & 11.66 & 24 & 9 \\
Qatar & $11(92)$ & 3.89 & 6 & 5 \\
Sudan & $22(129)$ & 7.77 & 2 & 20 \\
Total & $283(2075)$ & 100 & 210 & 73 \\
\hline
\end{tabular}

Note: The number of conventional and Islamic banks is based on the classification and list provided by the Orbis bank-focus database. The actual number of banks used in the analysis may vary from model to model. Source: Author's calculation based on Orbis Bank-Focus database

Various sources were used to collect the data: i) the Bureau van Dijk Orbis Bank-Focus database for bank-specific data; ii) the Financial Access Survey (FAS), International Monetary Fund (IMF), Global Findex databases and individual country's central bank report for DFI data; iii) World Development Indicators (WDI), and World Bank database for macroeconomic factors; and iv) previous literature for instrumental variable data.

\subsection{Model Development}

We set up proxies for bank risk-taking, DFI, and other control variables to test the effect of DFI on bank risk-taking in dual banking countries.

2 Based on IFSB Stability Report 2018 


\section{a. Bank Risk-taking}

Three proxies were considered for bank risk-taking: a) default risk, b) leverage risk, and c) portfolio risk, as dependent variables following Danisman and Tarazi (2020) and Khan, Scheule, and Wu (2017). We employed the z-score for default risk, as this is a widely used and well-accepted proxy for bank risk-taking or stability in the banking literature (Danisman \& Tarazi, 2020; Houston, Lin, Lin, \& Ma, 2010; Laeven \& Levine, 2009). We considered bank risk-taking to be the opposite of bank stability. The following formula was used to calculate the z-score:

$$
Z-\operatorname{score}_{i t}=\frac{R O A A_{i t}+E Q T_{i t}}{\sigma(R O A A)_{i t}}
$$

where $R O A A_{i t}, E Q T_{i t}$ and $\sigma(R O A A)_{i t}$ are the return on average assets, the equity to assets ratio, and the standard deviation (sd) of ROAA of bank $i$ in year $t$, respectively. To calculate $\sigma(R O A A)$, we considered 3-year rolling time windows, which are generally sufficient to allow for variation in the z-score. As the z-score is highly skewed, we took the natural logarithm to reduce the skewness. The ratio implies that the higher the value, the lower banks' risk-taking. To simplify the analysis, we multiplied (-1) by the $\log (\mathrm{z}$-score), which suggests that the higher the value, the higher the risk-taking. We denoted it as default risk (DR). We also decomposed the z-score to obtain the leverage and portfolio risk. Leverage risk $(\mathrm{LR})$ and portfolio risk (PR) were proxied by EQT/ $\sigma(R O A A)$ and ROAA/ $\sigma(R O A A)$ respectively, following the studies of Danisman and Tarazi (2020) and Lepetit et al. (2008). We also took the natural logarithm and multiplied (-1) by both proxies for simplicity, in which a higher value represents higher risk-taking.

\section{b. Digital Financial Inclusion Index}

We estimated proxies for digital financial inclusion to find the DFI-bank risktaking nexus. It was quite difficult to estimate proxies and/or index for DFI due to the unavailability of relevant data. However, based on the available data on the FAS and Global Findex databases, we took variables that were solely related to digital financial activities, including mobile and internet-based financial services, which can be enjoyed through electronic devices in a cashless manner. In the case of missing values for a particular year, we looked at each country's central bank database, and also used the average value technique. Following previous studies (e.g., Ahamed \& Mallick, 2019; Banna \& Alam, 2020; Banna et al., 2020a) on financial inclusion and banking performance, we also considered both the access (supply side) and usage (demand side) penetrations for our digital financial inclusion index. Previous studies have employed the number of ATMs, bank branches, and bank accounts as financial inclusion proxies. In this study, mobile money agent and POS (point of sale) terminals per 100,000 adults (AGT_AD), and mobile money agent outlets per 1,000 $\mathrm{km}^{2}$ (AGT_KM) for the supply side (both geographic and demographic outreach - access to digital finance penetration) were considered. For the demand side (use of digital finance penetration) - the number of mobile money accounts per 1,000 adults (ACT_AD), the number of mobile and internet 
banking transactions (during the reference year) per 1,000 adults (TRANS_N), and the value of mobile and internet banking transactions (during the reference year) (\% of GDP) (TRANS_V) were employed.

Since the proxies used in building the DFI index were highly correlated with each other, an inclusive DFI index was constructed to capture the common variation among the proxies using principal component analysis (henceforth $\mathrm{PCA}^{3}$ ). This index dealt sufficiently with the setback of multicollinearity and over-parameterisation as a single measure of DFI (Ahamed \& Mallick, 2019). We measured both the supply side (ACCESS) index and the demand side (USAGE) index separately using the PCA. Finally, we combined the two indices to create a comprehensive digital financial index (DFI) using the PCA. All three indices were normalised using the minimum-maximum normalisation technique to avoid unnecessary negative values.

\section{c. Bank and Macroeconomic Variables}

We also controlled for bank-specific as well as country-specific (macroeconomic) factors in our analysis. Following previous banking literature (e.g., Ahamed \& Mallick, 2019; Houston et al., 2010; Laeven \& Levine, 2009), we considered the following variables as our control variables. For the bank-level variables, to control the potential size effect of an individual bank, the logarithm of total assets (Bank size - BSIZE) was used, while the ratio of total loans to total assets (Loan share - LSH) was employed to account for the liquidity risk of individual banks. To control deposit share, a proxy of the ratio of total deposits to total assets (Deposit share - DSH) was used. As better management quality can reduce any excessive risk-taking tendency, the ratio of total earning assets to total assets (Management quality - MGTQ) was taken into consideration. We also controlled the annual growth of total assets (Asset growth - AG). In addition, for the country-level variables, we controlled two macroeconomic variables, namely real GDP per capita growth (GDPPCG) and inflation (INFL).

\subsection{Methods}

To investigate the impact of DFI on bank risk-taking, the following baseline regression analysis was used:

$$
Y_{i j t}=\alpha+\beta D F I_{j t}+\emptyset X_{i j t}+\omega Z_{j t}+\varepsilon_{i j t}
$$

where $Y_{i j t}=D R, L R$ and $P R$ as dependent variables, which are the proxies for the bank risk-taking of bank $i$ of country $j$ in year $t ; D F I_{j t}=$ the digital financial inclusion index of country $j$ in year $t ; X_{i j t}=$ bank-specific factors of bank $i$ of country $j$ in year $t ; Z_{j t}=$ macroeconomic factors of country $j$ in year $t$; and $\beta, \emptyset, \omega=$ coefficients of the variables and $\varepsilon_{i j t}=$ Error term.

3 We do not provide the PCA results, but they are available upon request. 
The study used both static and dynamic models to make the findings more robust. Primarily, the panel-corrected standard errors (PCSEs) method of Beck and Katz (1995) was employed, following Alfadli and Rjoub (2019), to find the relationship between DFI and bank risk-taking. There were two main reasons for choosing this method: i) it reduces prevailing sequential correlation and crosssectional dependency problems; and ii) using a suitable instrument, it captures the likelihood of endogeneity among the dependent factors and some of the independent factors in a particular model. Subsequently, to minimise potential endogeneity issues in the form of reverse causality, and following Kim, Batten, and Ryu (2020) and Ahamed and Mallick (2019), the two-stage panel least squares - instrumental variables (2SLS-IV) method was also used to check the robustness of the results.

Furthermore, dynamic panel two-step system generalised method of moments (GMM) was also used to validate the results. We chose GMM because it tackles several of the main econometric issues (Ahamed \& Mallick, 2019) related to this study: i) it eradicates the presence of unobserved bank-specific effects by considering the first differences of the independent variables; ii) it mitigates the endogeneity issue by using lags of the independent variables; and iii) it also captures the dynamic relationship between bank risk-taking and DFI.

\section{RESULTS}

\subsection{Results}

This section provides the descriptive statistics of the study, the main findings and analysis of the relationship between bank risk-taking and DFI. The results of various robustness tests are also reported here.

\subsubsection{Descriptive statistics}

Table 2 shows the descriptive statistics of the variables used in this study for both conventional and Islamic banks. Panels A, B and C provide the descriptive statistics of the full sample, conventional banks and Islamic banks respectively.

Table 2.

Descriptive Statistics

\begin{tabular}{lcccccc}
\hline \multicolumn{1}{c}{ Variable } & Obs & Mean & Std.Dev. & Min & Max & t-test (mean) \\
\hline $\begin{array}{l}\text { Panel A: Full Sample } \\
\text { Bank-Specific }\end{array}$ & & & & & & \\
DR (Default risk) & 1773 & -3.936 & 1.324 & -9.158 & 3.647 & $-1.9876^{* *}$ \\
LR (Leverage risk) & 1779 & -3.841 & 1.283 & -9.087 & 1.597 & $-2.2860^{* *}$ \\
PR (Portfolio risk) & 1640 & -1.551 & 1.481 & -6.945 & 5.617 & -0.7233 \\
Bank size (BSIZE) & 2075 & 7.481 & 1.865 & -1.332 & 12.467 & $4.3986^{* * *}$ \\
LSH (Loan share) & 2066 & .585 & .174 & 0 & .999 & -1.2411 \\
DSH (Deposit share) & 2044 & .763 & .182 & 0 & 2.231 & $-4.0507^{* * *}$ \\
AG (Asset growth) & 1822 & 16.205 & 25.951 & -89.66 & 286.641 & $-2.1339^{* *}$ \\
MGTQ (Managerial quality) & 2070 & .822 & .144 & 0 & 1 & $4.0088^{* * *}$ \\
\hline
\end{tabular}


Table 2.

Descriptive Statistics (Continued)

\begin{tabular}{|c|c|c|c|c|c|c|}
\hline Variable & Obs & Mean & Std.Dev. & Min & Max & t-test (mean) \\
\hline \multicolumn{7}{|c|}{ Digital Financial Inclusion-Specific } \\
\hline AGT_KM & 2075 & 974.019 & 2062.686 & .107 & 7315.652 & \\
\hline AGT_AD & 2075 & 580.833 & 403.919 & .099 & 1386.422 & \\
\hline ACT_AD & 2075 & 268.716 & 295.217 & .017 & 1099.462 & \\
\hline TRANS_N & 2075 & 48306.7 & 95871.5 & 0 & 462000 & \\
\hline TRANS_V & 2075 & 124.553 & 156.538 & 0 & 566.76 & \\
\hline DFI & 2075 & .343 & .261 & 0 & 1 & \\
\hline ACCESS & 2075 & .312 & .259 & 0 & 1 & \\
\hline USAGE & 2075 & .304 & .257 & 0 & 1 & \\
\hline \multicolumn{7}{|l|}{ Macroeconomic-specific } \\
\hline $\begin{array}{l}\text { GDPPCG (GDP per capita } \\
\text { growth) }\end{array}$ & 2075 & 3.802 & 2.102 & -4.858 & 13.564 & \\
\hline INFL (Inflation) & 2075 & 6.326 & 7.578 & -.667 & 63.293 & \\
\hline \multicolumn{7}{|l|}{ Instrumental variables } \\
\hline $\mathrm{FnF}$ & 1871 & 38.079 & 14.597 & 22.315 & 77.153 & \\
\hline MSH & 2075 & .078 & .026 & .012 & .12 & \\
\hline \multicolumn{7}{|c|}{ Panel B: Conventional banks } \\
\hline $\mathrm{DR}$ & 1301 & -3.974 & 1.338 & -9.158 & 2.879 & \\
\hline LR & 1305 & -3.883 & 1.297 & -9.087 & 1.597 & \\
\hline PR & 1201 & -1.567 & 1.523 & -6.945 & 5.617 & \\
\hline BSIZE & 1517 & 7.59 & 1.802 & -1.332 & 12.467 & \\
\hline LSH & 1513 & .582 & .167 & 0 & .999 & \\
\hline DSH & 1500 & .753 & .162 & 0 & .987 & \\
\hline AG & 1329 & 15.416 & 24.538 & -89.66 & 280.738 & \\
\hline MGTQ & 1516 & .83 & .111 & .002 & 1 & \\
\hline \multicolumn{7}{|l|}{ Panel C: Islamic banks } \\
\hline $\mathrm{DR}$ & 472 & -3.833 & 1.28 & -7.854 & 3.647 & \\
\hline LR & 474 & -3.726 & 1.236 & -7.852 & 1.331 & \\
\hline PR & 439 & -1.507 & 1.36 & -5.407 & 3.896 & \\
\hline BSIZE & 558 & 7.186 & 1.996 & -.302 & 11.001 & \\
\hline LSH & 553 & .593 & .192 & .007 & .979 & \\
\hline DSH & 544 & .79 & .224 & 0 & 2.231 & \\
\hline $\mathrm{AG}$ & 493 & 18.333 & 29.345 & -53.823 & 286.641 & \\
\hline MGTQ & 554 & .801 & .208 & 0 & .997 & \\
\hline
\end{tabular}

Table 2 shows that, based on the mean t-test, conventional banks are significantly different to Islamic ones with respect to all types of ratios, apart from the loan share ratio. Moreover, in terms of bank risk-taking, Islamic banks tend to have more of a tendency towards this than conventional banks, especially in terms of default risk and leverage risk. However, no significant difference was found between Islamic and conventional banks with regard to portfolio risk. 


\section{DEFAULT RISK}

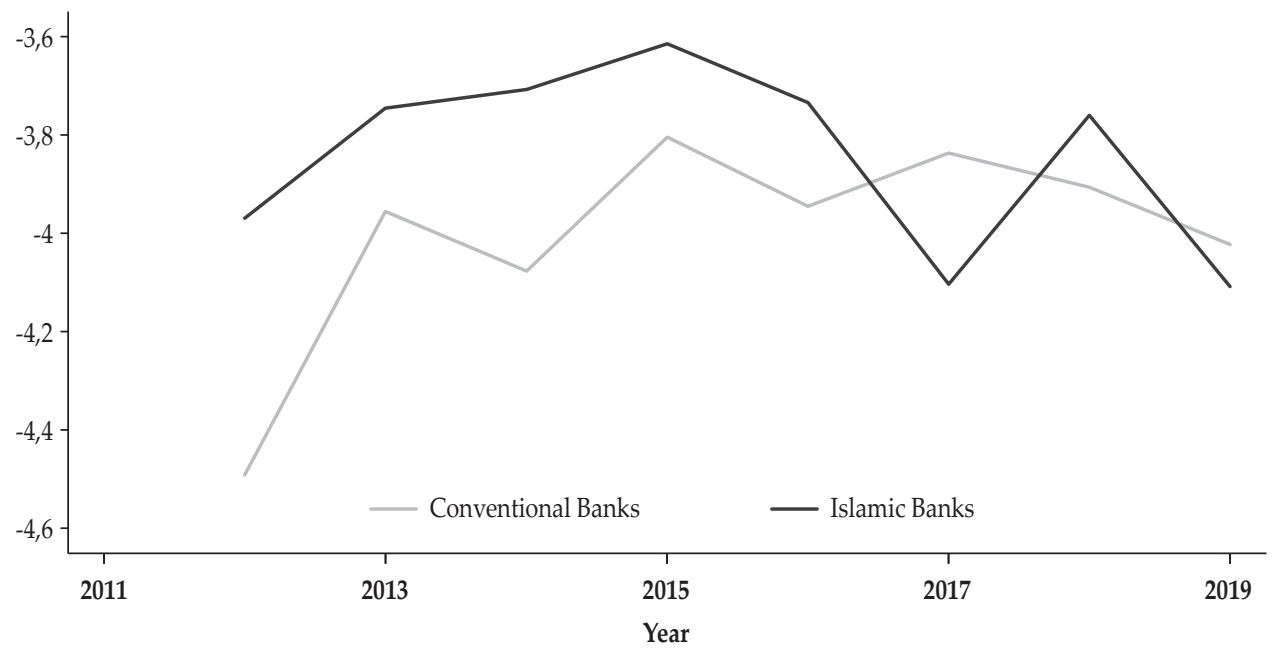

Source: Author's calculation based on Orbis Bank- Focus database

\section{LEVARAGE RISK}

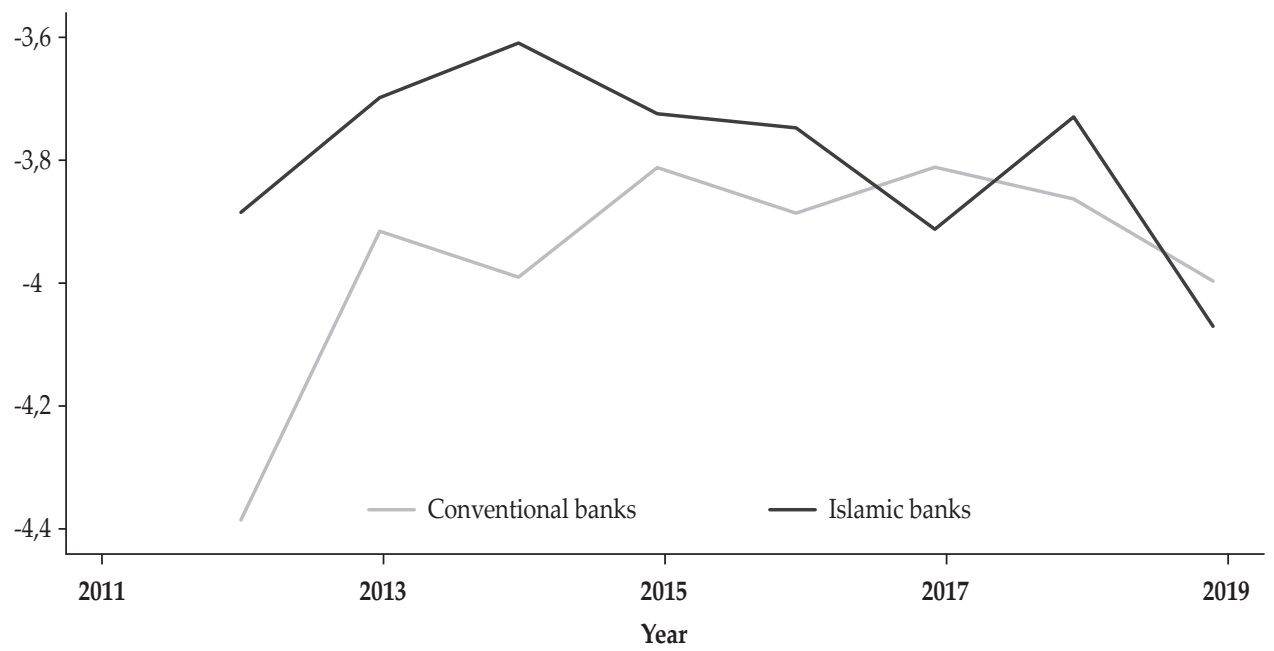

Source: Author's calculation based on Orbis Bank- Focus database

Figure 1.

Various Risk-Taking Comparisons between Islamic and Conventional Banks 


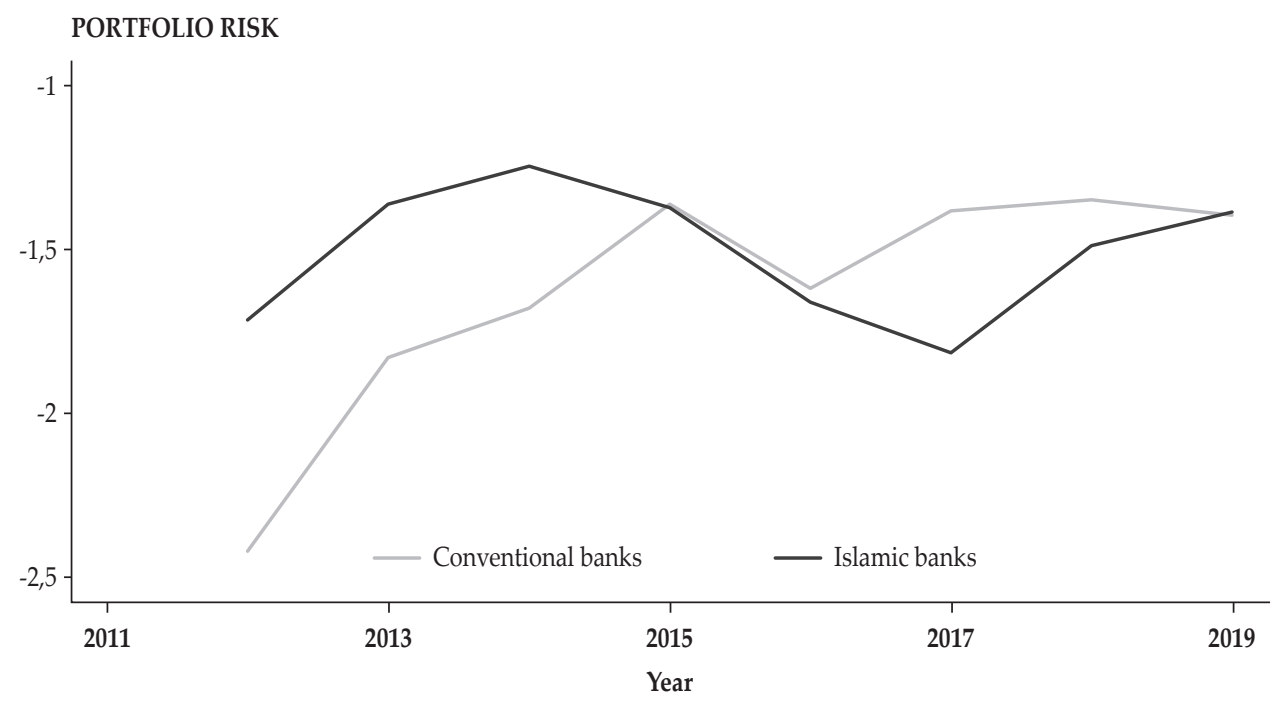

Source: Author's calculation based on Orbis Bank- Focus database

Figure 1.

Various Risk-Taking Comparisons between Islamic and Conventional Banks (Continued)

Figure 1 highlights noteworthy differences in the various types of risk-taking of the conventional and Islamic banks throughout the sample period (2011 to 2019), apart from 2017. Hence, it is suggested that the bank types differ significantly in terms of risk-taking, with Islamic banks showing a higher degree of risk-taking, but a lower degree of bank stability, compared to conventional banks.

Moreover, on average the sample countries have 974 and 580 agent outlets per $1000 \mathrm{~km}^{2}$ and per 100k adults respectively. Furthermore, the number of mobile money and e-money accounts per 1000 adults is 269, and the number and the value of mobile money and internet banking transactions per 1000 adults are approximately 48307 and 125 respectively. This indicates that existing bank account and mobile money holders are well snug of using the internet and mobile facilities provided by the banks and/or other financial institutions in the sample areas. 


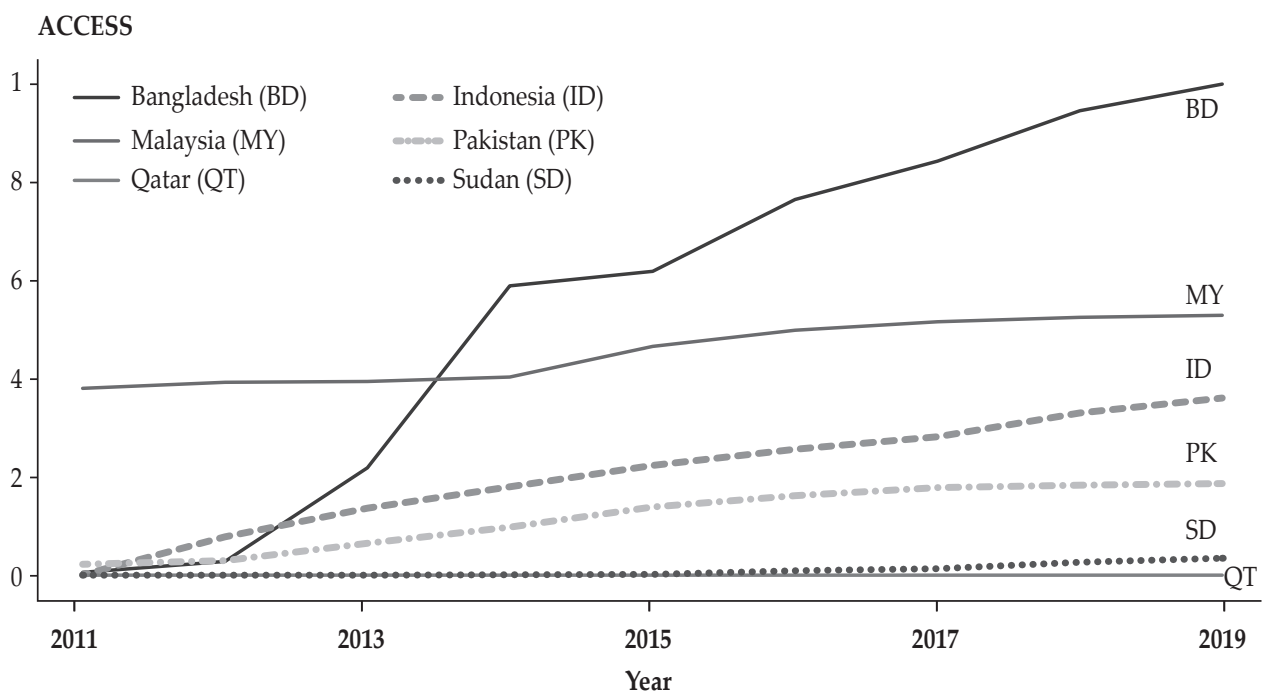

Source: Author's calculation based on Orbis Bank- Focus database

\section{USAGE}

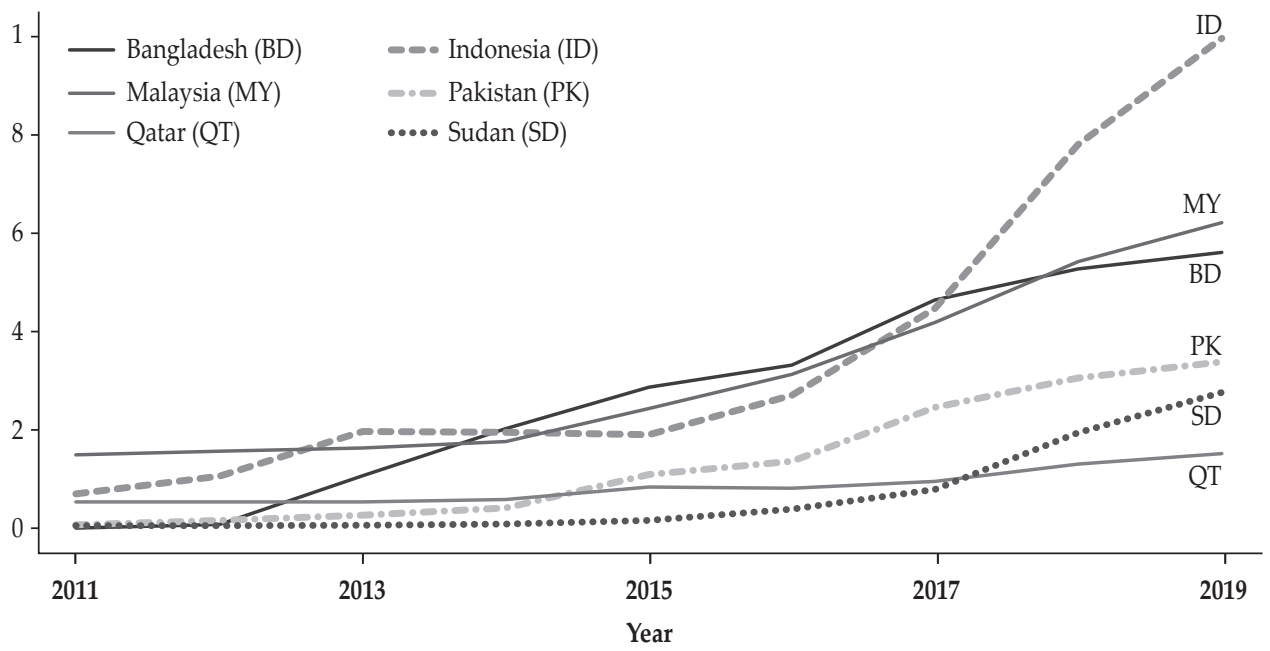

Source: Author's calculation based on Orbis Bank- Focus database

Figure 2.

Country and Year-wise DFI Indexes 


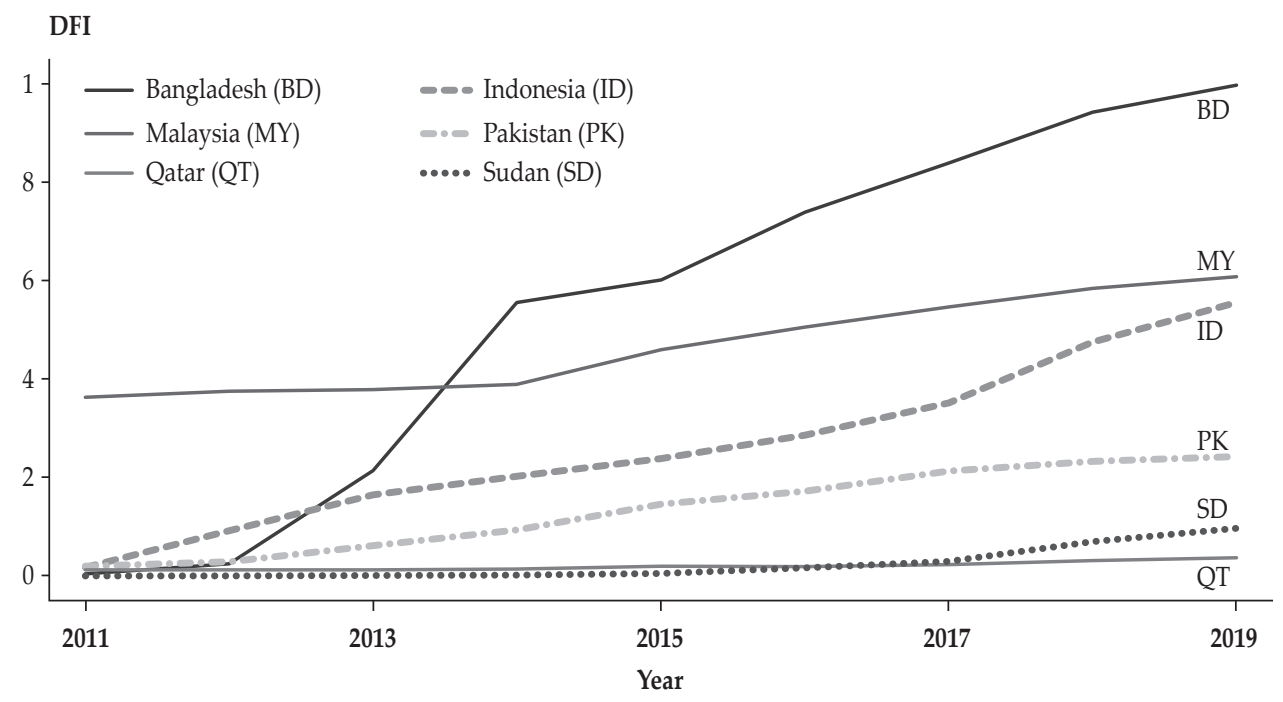

Source: Author's calculation based on Orbis Bank- Focus database

Figure 2.

Country and Year-wise DFI Indexes (Continued)

In addition, Figure 2 shows that on an average among the sample countries, Bangladesh has a better score for the overall DFI index and ACCESS index, followed by Malaysia, while Indonesia is in a better position in terms of the USAGE index. On the other hand, Qatar and Sudan have the lowest scores in all the indices. Regarding yearly improvement in the index, most of the countries show an upward trend. However, the mixed scoring positions of the sample countries suggests that there is scope to enhance the DFI index scores.

\subsubsection{Digital Financial Inclusion and Bank Risk-taking}

This subdivision presents the main results of the study. We started our estimation by running the panel-corrected standard errors (PCSEs) regression model to find the nexus between bank risk-taking and DFI (shown in Table 3) using the full sample. The reasons behind choosing this method were: i) it has the ability to reduce prevailing sequential correlation and cross-sectional dependence problems, and ii) it captures the likelihood of endogeneity among the dependent and some of the independent factors in a particular model using a suitable instrument (Alfadli \& Rjoub, 2019).

Our analysis is based on two dimensions: first, three proxies of bank risktaking - DR (Models 1-3), LR (Models 4-6) and PR (Models 7-9) and second, three indices of DFI - the Overall DFI index (Models 1, 4 and 7), ACCESS (Models 2, 5 and 8 ) and USAGE (models 3, 6 and 9), as shown in Table 3. We also controlled both bank-specific variables, such as BSIZE, LSH, DSH and MGTQ, and macroeconomic variables, such as GDPPCG and INFL. Moreover, we took Islamic banks (1= Islamic bank, $0=$ otherwise) as a dummy and also controlled for year, bank, and country effects. 
Table 3.

DFI and Bank Risk-Taking Using the PCSEs Regression Model (Full Sample)

\begin{tabular}{|c|c|c|c|c|c|c|c|c|c|}
\hline & \multicolumn{3}{|c|}{ DR } & \multicolumn{3}{|c|}{ LR } & \multicolumn{3}{|c|}{ PR } \\
\hline & $(1)$ & (2) & (3) & $(4)$ & (5) & (6) & $(7)$ & (8) & (9) \\
\hline & DFI & ACCESS & USAGE & DFI & ACCESS & USAGE & DFI & ACCESS & USAGE \\
\hline \multirow{2}{*}{ DFI } & $-1.214^{* * *}$ & $-0.827^{* * * *}$ & $-0.728^{* * * *}$ & $-1.224^{* * * *}$ & $-0.825^{* * *}$ & $-0.768^{* * * *}$ & $-0.789^{* * *}$ & $-0.688^{* * *}$ & 0.048 \\
\hline & $(0.224)$ & $(0.199)$ & $(0.219)$ & $(0.219)$ & $(0.196)$ & $(0.214)$ & $(0.253)$ & $(0.224)$ & $(0.261)$ \\
\hline \multirow{2}{*}{ BSIZE } & $-0.232^{* * *}$ & $-0.240^{* * * *}$ & $-0.260^{* * *}$ & $-0.210^{* * *}$ & $-0.218^{* * *}$ & $-0.237^{* * *}$ & $-0.280^{* * *}$ & $-0.280^{* * *}$ & $-0.301^{* * *}$ \\
\hline & $(0.033)$ & $(0.033)$ & $(0.031)$ & $(0.031)$ & $(0.031)$ & $(0.029)$ & $(0.036)$ & $(0.036)$ & $(0.035)$ \\
\hline \multirow{2}{*}{ LSH } & $-1.112^{* * *}$ & $-1.106^{* * *}$ & $-0.798^{* * *}$ & $-1.158^{* * *}$ & $-1.150^{* * *}$ & $-0.836^{* * *}$ & $-1.559^{* * *}$ & $-1.592^{* * *}$ & $-1.443^{* * *}$ \\
\hline & $(0.287)$ & $(0.291)$ & $(0.292)$ & $(0.276)$ & $(0.279)$ & $(0.281)$ & $(0.306)$ & $(0.307)$ & $(0.308)$ \\
\hline \multirow{2}{*}{ DSH } & $0.585^{* *}$ & $0.612^{* *}$ & $0.620^{* *}$ & $0.549^{* *}$ & $0.578^{* *}$ & $0.585^{* *}$ & 0.126 & 0.136 & 0.170 \\
\hline & $(0.237)$ & $(0.238)$ & $(0.242)$ & $(0.233)$ & $(0.235)$ & $(0.237)$ & $(0.246)$ & $(0.245)$ & $(0.250)$ \\
\hline \multirow{2}{*}{ AG } & $-0.003^{* *}$ & $-0.003^{* *}$ & $-0.003^{* *}$ & $-0.003^{* *}$ & $-0.003^{* *}$ & $-0.002^{*}$ & $-0.003^{*}$ & $-0.003^{*}$ & $-0.003^{*}$ \\
\hline & $(0.001)$ & $(0.001)$ & $(0.001)$ & $(0.001)$ & $(0.001)$ & $(0.001)$ & $(0.002)$ & $(0.002)$ & $(0.002)$ \\
\hline \multirow{2}{*}{ MGTQ } & -0.084 & -0.092 & -0.455 & -0.046 & -0.056 & -0.432 & -0.452 & -0.416 & -0.592 \\
\hline & $(0.349)$ & $(0.352)$ & $(0.354)$ & $(0.351)$ & $(0.354)$ & $(0.354)$ & $(0.385)$ & $(0.386)$ & $(0.387)$ \\
\hline \multirow{2}{*}{ GDPPCG } & 0.016 & -0.000 & -0.024 & 0.022 & 0.005 & -0.018 & 0.002 & -0.001 & -0.033 \\
\hline & $(0.023)$ & $(0.023)$ & $(0.021)$ & $(0.023)$ & $(0.023)$ & $(0.021)$ & $(0.027)$ & $(0.026)$ & $(0.024)$ \\
\hline \multirow{2}{*}{ INFL } & $0.012^{* *}$ & $0.013^{* *}$ & 0.008 & $0.017^{* * *}$ & $0.018^{* * *}$ & $0.013^{* *}$ & $-0.017^{* * *}$ & $-0.016^{* *}$ & $-0.016^{* * *}$ \\
\hline & $(0.005)$ & $(0.005)$ & $(0.005)$ & $(0.005)$ & $(0.005)$ & $(0.005)$ & $(0.006)$ & $(0.006)$ & $(0.006)$ \\
\hline \multirow[t]{2}{*}{ Islamic bank } & $0.149^{* *}$ & $0.138^{*}$ & 0.058 & $0.159^{* *}$ & $0.148^{* *}$ & 0.067 & $0.317^{* * *}$ & $0.321^{* * *}$ & $0.265^{* * *}$ \\
\hline & $(0.073)$ & $(0.074)$ & $(0.072)$ & $(0.072)$ & $(0.072)$ & $(0.070)$ & $(0.086)$ & $(0.087)$ & $(0.085)$ \\
\hline $\begin{array}{l}\text { Country-fixed } \\
\text { effect }\end{array}$ & Yes & Yes & Yes & Yes & Yes & Yes & Yes & Yes & Yes \\
\hline $\begin{array}{l}\text { Year-fixed } \\
\text { effect }\end{array}$ & Yes & Yes & Yes & Yes & Yes & Yes & Yes & Yes & Yes \\
\hline $\begin{array}{l}\text { Bank-fixed } \\
\text { effect }\end{array}$ & Yes & Yes & Yes & Yes & Yes & Yes & Yes & Yes & Yes \\
\hline Obs. & 1740 & 1740 & 1740 & 1746 & 1746 & 1746 & 1609 & 1609 & 1609 \\
\hline $\mathrm{R}^{2}$ & 0.114 & 0.110 & 0.108 & 0.118 & 0.113 & 0.112 & 0.138 & 0.138 & 0.133 \\
\hline
\end{tabular}

Robust standard errors are shown in parentheses.

*** $p<0.01,{ }^{* *} p<0.05$, and * $p<0.1$

The results in Table 3 suggest that for the full sample overall DFI has a negative impact on bank default risk, leverage risk, and portfolio risk, as shown by the negative coefficient of overall DFI. The relationship is significant at the $1 \%$ level for all types of bank risk-taking. Furthermore, ACCESS has also a negative relationship with DR, LR, and PR at the 1\% level of significance, while USAGE has a negative relation with DR and LR, also at the $1 \%$ level of significance. However, USAGE has a positive relation with $\mathrm{PR}$, which is insignificant. These relationships imply that for each of the reported specifications, the stronger the digitally inclusive financial system is, the lower the level of bank-risk tendency, which means that development of digital finance stabilises the banking sector. Moreover, BSIZE, LSH, AG, and MGTQ have a negative relationship with all types of bank risktaking; of these, BSIZE, LSH and AG are significant, but MGTQ is insignificant. On the other hand, DSH has a positive relationship with the level of bank risk-taking and is significant for DR and LR, but insignificant for PR. INFL and GDPPCG have 
a mixed relationship with the level of bank risk-taking, with INFL significant but GDPPCG insignificant in all specifications.

\subsubsection{Islamic vs Conventional Banks: DFI and Bank Risk-taking}

In this subsection, we split our sample based on bank type (conventional or Islamic) to observe how DFI affects the individual bank-type industry. This was done because Islamic banks are relatively new compared to conventional ones, and most of the latter adopted fintech-based technologies in their existing operational activities earlier than Islamic banks. In addition, the two banking operational philosophies are also different. Therefore, we expect a significant difference in the DFI-bank risk-taking nexus for both types of banking. Table 4 shows the association of DFI with Islamic bank risk-taking, while Table 5 shows this with conventional banks. In the two tables, we did not control the Islamic bank dummy, as we had already riven our sample based on bank type. We consider 73 Islamic banks in Table 4 and 210 conventional ones in Table 5, as our new sample size and PCSEs model have also been considered for this analysis.

Table 4.

DFI and Bank Risk-Taking Using the PCSEs Regression Model (Islamic Banks)

\begin{tabular}{|c|c|c|c|c|c|c|c|c|c|}
\hline & \multicolumn{3}{|c|}{ DR } & \multicolumn{3}{|c|}{ LR } & \multicolumn{3}{|c|}{ PR } \\
\hline & (1) & (2) & (3) & (4) & (5) & (6) & (7) & (8) & (9) \\
\hline & DFI & ACCESS & USAGE & DFI & ACCESS & USAGE & DFI & ACCESS & USAGE \\
\hline \multirow{2}{*}{ DFI } & 0.081 & 0.267 & -0.790 & 0.056 & 0.232 & -0.750 & $0.723^{*}$ & 0.284 & $1.934^{* * *}$ \\
\hline & $(0.347)$ & $(0.327)$ & $(0.486)$ & $(0.340)$ & $(0.321)$ & $(0.486)$ & $(0.403)$ & $(0.385)$ & $(0.553)$ \\
\hline \multirow{2}{*}{ BSIZE } & $-0.409^{* * *}$ & $-0.413^{* * *}$ & $-0.398^{* * *}$ & $-0.369^{* * *}$ & $-0.373^{* * *}$ & $-0.359^{* * *}$ & $-0.504^{* * *}$ & $-0.495^{* * *}$ & $-0.495^{* * *}$ \\
\hline & $(0.071)$ & $(0.072)$ & $(0.069)$ & $(0.061)$ & $(0.062)$ & $(0.059)$ & $(0.072)$ & $(0.073)$ & $(0.070)$ \\
\hline \multirow{2}{*}{ LSH } & -0.058 & -0.032 & -0.227 & 0.007 & 0.032 & -0.151 & -0.105 & -0.209 & 0.264 \\
\hline & $(0.633)$ & $(0.630)$ & $(0.616)$ & $(0.572)$ & $(0.570)$ & $(0.560)$ & $(0.759)$ & $(0.757)$ & $(0.766)$ \\
\hline \multirow{2}{*}{ DSH } & 0.552 & 0.557 & 0.502 & 0.656 & 0.661 & 0.610 & $1.113^{*}$ & $1.104^{*}$ & $1.153^{*}$ \\
\hline & $(0.495)$ & $(0.497)$ & $(0.494)$ & $(0.462)$ & $(0.463)$ & $(0.463)$ & $(0.635)$ & $(0.639)$ & $(0.594)$ \\
\hline \multirow{2}{*}{ AG } & -0.002 & -0.002 & -0.003 & -0.002 & -0.002 & -0.002 & $-0.006^{* *}$ & $-0.007^{* *}$ & $-0.006^{* *}$ \\
\hline & $(0.002)$ & $(0.002)$ & $(0.002)$ & $(0.002)$ & $(0.002)$ & $(0.002)$ & $(0.003)$ & $(0.003)$ & $(0.003)$ \\
\hline \multirow{2}{*}{ MGTQ } & -0.895 & $-0.967^{*}$ & -0.717 & -0.886 & $-0.953^{*}$ & -0.724 & -1.116 & -0.942 & $-1.307^{* *}$ \\
\hline & $(0.565)$ & $(0.561)$ & $(0.548)$ & $(0.551)$ & $(0.547)$ & $(0.536)$ & $(0.682)$ & $(0.677)$ & $(0.659)$ \\
\hline \multirow{2}{*}{ GDPPCG } & $-0.047^{*}$ & $-0.054^{*}$ & -0.030 & -0.043 & $-0.049^{*}$ & -0.028 & -0.049 & -0.035 & $-0.057^{*}$ \\
\hline & $(0.029)$ & $(0.029)$ & $(0.026)$ & $(0.029)$ & $(0.028)$ & $(0.026)$ & $(0.034)$ & $(0.034)$ & $(0.030)$ \\
\hline \multirow{2}{*}{ INFL } & 0.001 & 0.001 & 0.001 & 0.007 & 0.006 & 0.006 & $-0.017^{* *}$ & $-0.017^{*}$ & -0.012 \\
\hline & $(0.007)$ & $(0.007)$ & $(0.007)$ & $(0.007)$ & $(0.007)$ & $(0.007)$ & $(0.008)$ & $(0.009)$ & $(0.008)$ \\
\hline $\begin{array}{l}\text { Country- } \\
\text { fixed effect }\end{array}$ & Yes & Yes & Yes & Yes & Yes & Yes & Yes & Yes & Yes \\
\hline $\begin{array}{l}\text { Year-fixed } \\
\text { effect }\end{array}$ & Yes & Yes & Yes & Yes & Yes & Yes & Yes & Yes & Yes \\
\hline $\begin{array}{l}\text { Bank-fixed } \\
\text { effect }\end{array}$ & Yes & Yes & Yes & Yes & Yes & Yes & Yes & Yes & Yes \\
\hline Obs. & 455 & 455 & 455 & 457 & 457 & 457 & 423 & 423 & 423 \\
\hline $\mathrm{R}^{2}$ & 0.239 & 0.240 & 0.245 & 0.241 & 0.242 & 0.246 & 0.237 & 0.233 & 0.262 \\
\hline
\end{tabular}

Robust standard errors are shown in parentheses.

${ }^{* * *} p<0.01,{ }^{* *} p<0.05$, and ${ }^{*} p<0.1$ 
In Table 4, in relation to Islamic banks, the overall DFI interestingly has a positive relationship with the level of bank risk-taking, although the relationship is insignificant, apart from PR, which is significant at the $10 \%$ level. ACCESS has a positive relationship with bank risk-taking, but is insignificant in all specifications. USAGE has a mixed relationship with bank risk-taking. It is negatively related with DR and LR, although at insignificant levels, but is significantly related with PR. Compared to to commercial banks overall, LSH and AG are insignificant, but MGTQ and GDPPCG are negative and have mixed significance for the Islamic banks.

Table 5.

DFI and Bank Risk-Taking Using the PCSEs Regression Model (Conventional Banks)

\begin{tabular}{|c|c|c|c|c|c|c|c|c|c|}
\hline & \multicolumn{3}{|c|}{ DR } & \multicolumn{3}{|c|}{ LR } & \multicolumn{3}{|c|}{ PR } \\
\hline & (1) & (2) & (3) & (4) & (5) & (6) & (7) & (8) & (9) \\
\hline & DFI & ACCESS & USAGE & DFI & ACCESS & USAGE & DFI & ACCESS & USAGE \\
\hline DFI & $\begin{array}{l}-1.710^{* * *} \\
(0.288)\end{array}$ & $\begin{array}{l}-1.128^{* * *} \\
(0.242)\end{array}$ & $\begin{array}{l}-0.753^{* * *} \\
(0.261)\end{array}$ & $\begin{array}{l}-1.723^{* * *} \\
(0.280)\end{array}$ & $\begin{array}{l}-1.124^{* * *} \\
(0.237)\end{array}$ & $\begin{array}{l}-0.808^{* * *} \\
(0.254)\end{array}$ & $\begin{array}{l}-1.318^{* * * *} \\
(0.323)\end{array}$ & $\begin{array}{l}-0.900^{* * *} \\
(0.274)\end{array}$ & $\begin{array}{l}-0.513^{*} \\
(0.307)\end{array}$ \\
\hline BSIZE & $\begin{array}{l}-0.175^{* * *} \\
(0.037)\end{array}$ & $\begin{array}{l}-0.187^{* * *} \\
(0.038)\end{array}$ & $\begin{array}{l}-0.222^{* * *} \\
(0.035)\end{array}$ & $\begin{array}{l}-0.156^{* * *} \\
(0.036)\end{array}$ & $\begin{array}{l}-0.169^{* * *} \\
(0.036)\end{array}$ & $\begin{array}{l}-0.203^{* * *} \\
(0.034)\end{array}$ & $\begin{array}{l}-0.227^{* * *} \\
(0.043)\end{array}$ & $\begin{array}{l}-0.235^{* * *} \\
(0.043)\end{array}$ & $\begin{array}{l}-0.266^{* * *} \\
(0.041)\end{array}$ \\
\hline LSH & $\begin{array}{l}-1.496^{* * *} \\
(0.317)\end{array}$ & $\begin{array}{l}-1.506^{* * *} \\
(0.320)\end{array}$ & $\begin{array}{l}-1.067^{* * *} \\
(0.329)\end{array}$ & $\begin{array}{l}-1.570^{* * *} \\
(0.311)\end{array}$ & $\begin{array}{l}-1.578^{* * *} \\
(0.315)\end{array}$ & $\begin{array}{l}-1.128^{* * *} \\
(0.323)\end{array}$ & $\begin{array}{l}-1.987^{* * *} \\
(0.341)\end{array}$ & $\begin{array}{l}-2.010^{* * *} \\
(0.343)\end{array}$ & $\begin{array}{l}-1.687^{* * *} \\
(0.350)\end{array}$ \\
\hline DSH & $\begin{array}{l}0.891^{* * *} \\
(0.277)\end{array}$ & $\begin{array}{l}0.922^{2 * *} \\
(0.279)\end{array}$ & $\begin{array}{l}0.958^{* * *} \\
(0.285)\end{array}$ & $\begin{array}{l}0.789^{* * *} \\
(0.281)\end{array}$ & $\begin{array}{l}0.824^{* * *} \\
(0.283)\end{array}$ & $\begin{array}{l}0.860^{* * * *} \\
(0.288)\end{array}$ & $\begin{array}{l}0.213 \\
(0.272)\end{array}$ & $\begin{array}{l}0.236 \\
(0.273)\end{array}$ & $\begin{array}{l}0.261 \\
(0.282)\end{array}$ \\
\hline AG & $\begin{array}{l}-0.002 \\
(0.002)\end{array}$ & $\begin{array}{l}-0.002 \\
(0.002)\end{array}$ & $\begin{array}{l}-0.002 \\
(0.002)\end{array}$ & $\begin{array}{l}-0.002 \\
(0.001)\end{array}$ & $\begin{array}{l}-0.002 \\
(0.001)\end{array}$ & $\begin{array}{l}-0.001 \\
(0.001)\end{array}$ & $\begin{array}{l}-0.001 \\
(0.002)\end{array}$ & $\begin{array}{l}-0.001 \\
(0.002)\end{array}$ & $\begin{array}{l}-0.000 \\
(0.002)\end{array}$ \\
\hline MGTQ & $\begin{array}{l}-0.124 \\
(0.477)\end{array}$ & $\begin{array}{l}-0.042 \\
(0.482)\end{array}$ & $\begin{array}{l}-0.465 \\
(0.495)\end{array}$ & $\begin{array}{l}-0.062 \\
(0.483)\end{array}$ & $\begin{array}{l}0.018 \\
(0.487)\end{array}$ & $\begin{array}{l}-0.432 \\
(0.499)\end{array}$ & $\begin{array}{l}-0.484 \\
(0.492)\end{array}$ & $\begin{array}{l}-0.415 \\
(0.494)\end{array}$ & $\begin{array}{l}-0.717 \\
(0.506)\end{array}$ \\
\hline GDPPCG & $\begin{array}{l}0.035 \\
(0.041)\end{array}$ & $\begin{array}{l}0.005 \\
(0.040)\end{array}$ & $\begin{array}{l}-0.054 \\
(0.037)\end{array}$ & $\begin{array}{l}0.044 \\
(0.040)\end{array}$ & $\begin{array}{l}0.014 \\
(0.040)\end{array}$ & $\begin{array}{l}-0.045 \\
(0.036)\end{array}$ & $\begin{array}{l}-0.016 \\
(0.043)\end{array}$ & $\begin{array}{l}-0.037 \\
(0.043)\end{array}$ & $\begin{array}{l}-0.085^{* *} \\
(0.039)\end{array}$ \\
\hline INFL & $\begin{array}{l}0.000 \\
(0.020)\end{array}$ & $\begin{array}{l}0.005 \\
(0.020)\end{array}$ & $\begin{array}{l}-0.004 \\
(0.019)\end{array}$ & $\begin{array}{l}0.003 \\
(0.020)\end{array}$ & $\begin{array}{l}0.008 \\
(0.020)\end{array}$ & $\begin{array}{l}-0.002 \\
(0.020)\end{array}$ & $\begin{array}{l}-0.046^{* * *} \\
(0.017)\end{array}$ & $\begin{array}{l}-0.042^{* *} \\
(0.017)\end{array}$ & $\begin{array}{l}-0.047^{* * *} \\
(0.017)\end{array}$ \\
\hline $\begin{array}{l}\text { Country-fixed } \\
\text { effect }\end{array}$ & Yes & Yes & Yes & Yes & Yes & Yes & Yes & Yes & Yes \\
\hline $\begin{array}{l}\text { Year-fixed } \\
\text { effect }\end{array}$ & Yes & Yes & Yes & Yes & Yes & Yes & Yes & Yes & Yes \\
\hline $\begin{array}{l}\text { Bank-fixed } \\
\text { effect }\end{array}$ & Yes & Yes & Yes & Yes & Yes & Yes & Yes & Yes & Yes \\
\hline Obs. & 1285 & 1285 & 1285 & 1289 & 1289 & 1289 & 1186 & 1186 & 1186 \\
\hline $\mathrm{R}^{2}$ & 0.103 & 0.096 & 0.088 & 0.105 & 0.097 & 0.090 & 0.139 & 0.136 & 0.131 \\
\hline
\end{tabular}

Robust standard errors are shown in parentheses.

${ }^{* * *} p<0.01,{ }^{* *} p<0.05$, and ${ }^{*} p<0.1$

For conventional banks (as shown in Table 5), overall DFI, ACCESS and USAGE are significantly negatively associated with all types of bank risk-taking. The findings on all the other control variables are similar to those of the overall sample banks (in Table 3). 


\subsection{Robustness}

Though possible reverse causality (endogeneity) is a common identification issue in any banking research, it may be less of a problem in this study, as it investigates the role of DFI (a country-level indicator) in bank risk-taking (a bank-level indicator). Nevertheless, in order to ensure the robustness of the results and to minimise possible endogeneity issues, following Kim et al. (2020) the 2SLS-IV technique was conducted.

We searched recent empirical studies on banking stability/bank risk-taking and financial inclusion to choose suitable instrumental variables (IVs) to address any potential endogeneity issue. Following Ahamed and Mallick (2019) and Banna (2020b), this study considers the proportion of mobile phone subscriptions (per 100 people) (MSH) in other countries in the same region as an instrumental variable for the 2SLS-IV technique. We categorised countries based on high-income, and included South Asia, Europe \& Central Asia, Sub-Saharan Africa, East Asia \& Pacific, and the Middle East \& North Africa regions. It is argued that banking operation costs, as well as physical and financial infrastructural deficiencies, can be reduced through good communication infrastructure (Beck et al., 2007) and excessive use of mobile phones (Allen et al., 2014). Therefore, a large number of mobile subscriptions helps to make unbanked people banked, which will not directly affect bank risk-taking, but may influence DFI.

In addition, we consider the percentage of adults borrowing from friends and family during emergency funding $(\mathrm{FnF})$ as an instrumental variable. It has been found that the key source of borrowing during emergency situations in developing countries is friends and family (Demirguc-Kunt \& Klapper, 2012). It has also been shown that only $9 \%$ of the adults borrow from the formal financial sector, whereas $29 \%$ borrow from friends and family. The higher percentage of adults borrowing from friends and family may influence DFI, but will not directly affect banks' risk-taking tendency (Ahamed \& Mallick, 2019).

Table 6.

DFI and Bank Risk-Taking Using the 2SLS-IV Regression Model (Full Sample)

\begin{tabular}{cccccccccc}
\hline & \multicolumn{3}{c}{ DR } & \multicolumn{3}{c}{ LR } & \multicolumn{3}{c}{ PR } \\
\hline & $\mathbf{( 1 )}$ & $\mathbf{( 2 )}$ & $\mathbf{( 3 )}$ & $\mathbf{( 4 )}$ & $\mathbf{( 5 )}$ & $\mathbf{( 6 )}$ & $\mathbf{( 7 )}$ & $\mathbf{( 8 )}$ & $\mathbf{( 9 )}$ \\
\hline \multirow{2}{*}{ DFI } & DFI & ACCESS & USAGE & DFI & ACCESS & USAGE & DFI & ACCESS & USAGE \\
& $-1.523^{* * *}$ & $-1.076^{* * *}$ & $-0.633^{* *}$ & $-1.549^{* * *}$ & $-1.087^{* * *}$ & $-0.639^{* *}$ & $-1.178^{* * *}$ & $-0.912^{* *}$ & -0.277 \\
\multirow{3}{*}{ BSIZE } & $(0.419)$ & $(0.362)$ & $(0.265)$ & $(0.381)$ & $(0.330)$ & $(0.250)$ & $(0.453)$ & $(0.403)$ & $(0.332)$ \\
& $-0.142^{* *}$ & $-0.155^{* *}$ & $-0.195^{* * *}$ & $-0.119^{*}$ & $-0.133^{* *}$ & $-0.172^{* * *}$ & $-0.232^{* * *}$ & $-0.237^{* * *}$ & $-0.277^{* * *}$ \\
& $(0.067)$ & $(0.069)$ & $(0.064)$ & $(0.063)$ & $(0.064)$ & $(0.059)$ & $(0.059)$ & $(0.059)$ & $(0.055)$ \\
\multirow{2}{*}{ LSH } & $-0.909^{* *}$ & $-0.871^{* *}$ & $-0.809^{*}$ & $-0.949^{* *}$ & $-0.910^{* *}$ & $-0.833^{* *}$ & $-1.551^{* * *}$ & $-1.538^{* * *}$ & $-1.441^{* * *}$ \\
& $(0.412)$ & $(0.413)$ & $(0.420)$ & $(0.398)$ & $(0.398)$ & $(0.405)$ & $(0.426)$ & $(0.425)$ & $(0.431)$ \\
\multirow{2}{*}{ DSH } & 0.599 & $0.656^{*}$ & $0.659^{*}$ & 0.573 & 0.631 & 0.629 & -0.052 & -0.027 & 0.015 \\
& $(0.374)$ & $(0.373)$ & $(0.390)$ & $(0.392)$ & $(0.392)$ & $(0.409)$ & $(0.364)$ & $(0.363)$ & $(0.376)$ \\
\multirow{4}{*}{ AG } & -0.001 & -0.001 & -0.001 & -0.001 & -0.001 & -0.001 & -0.002 & -0.002 & -0.002 \\
& $(0.001)$ & $(0.001)$ & $(0.001)$ & $(0.001)$ & $(0.001)$ & $(0.001)$ & $(0.002)$ & $(0.002)$ & $(0.002)$ \\
& -0.676 & -0.667 & -0.855 & -0.573 & -0.564 & -0.771 & -0.913 & -0.893 & $-1.044^{*}$ \\
\multirow{2}{*}{ MGTQ } & $(0.499)$ & $(0.501)$ & $(0.526)$ & $(0.491)$ & $(0.492)$ & $(0.519)$ & $(0.577)$ & $(0.576)$ & $(0.606)$ \\
\hline
\end{tabular}


Table 6.

DFI and Bank Risk-Taking Using the 2SLS-IV Regression Model (Full Sample) (Continued)

\begin{tabular}{lccccccccc}
\hline & & DR & \multicolumn{3}{c}{ LR } & \multicolumn{3}{c}{ PR } \\
\hline & $\mathbf{( 1 )}$ & $\mathbf{( 2 )}$ & $\mathbf{( 3 )}$ & $\mathbf{( 4 )}$ & $\mathbf{( 5 )}$ & $\mathbf{( 6 )}$ & $\mathbf{( 7 )}$ & $\mathbf{( 8 )}$ & $\mathbf{( 9 )}$ \\
\hline \multirow{2}{*}{ GDPPCG } & DFI & ACCESS & USAGE & DFI & ACCESS & USAGE & DFI & ACCESS & USAGE \\
& $0.099^{* *}$ & $0.084^{*}$ & 0.006 & $0.117^{* * *}$ & $0.102^{* *}$ & 0.022 & 0.038 & 0.032 & -0.039 \\
& $(0.044)$ & $(0.043)$ & $(0.041)$ & $(0.042)$ & $(0.041)$ & $(0.040)$ & $(0.048)$ & $(0.049)$ & $(0.047)$ \\
INFL & 0.014 & 0.017 & 0.001 & $0.019^{*}$ & $0.021^{* *}$ & 0.006 & -0.015 & -0.012 & $-0.022^{* *}$ \\
& $(0.010)$ & $(0.010)$ & $(0.011)$ & $(0.010)$ & $(0.010)$ & $(0.011)$ & $(0.010)$ & $(0.010)$ & $(0.010)$ \\
Islamic bank & 0.236 & 0.211 & 0.150 & 0.234 & 0.209 & 0.147 & $0.490^{* * *}$ & $0.475^{* * *}$ & $0.408^{* *}$ \\
Country-fixed & $(0.152)$ & $(0.152)$ & $(0.143)$ & $(0.147)$ & $(0.147)$ & $(0.138)$ & $(0.168)$ & $(0.168)$ & $(0.162)$ \\
effect & Yes & Yes & Yes & Yes & Yes & Yes & Yes & Yes & Yes \\
Year-fixed & Yes & Yes & Yes & Yes & Yes & Yes & Yes & Yes & Yes \\
effect & & & & & & & & & \\
Bank-fixed & Yes & Yes & Yes & Yes & Yes & Yes & Yes & Yes & Yes \\
effect & & & & & & & & & \\
Obs. & 1572 & 1572 & 1572 & 1578 & 1578 & 1578 & 1445 & 1445 & 1445 \\
$R^{2}$ & 0.1025 & 0.0965 & 0.0943 & 0.1029 & 0.0962 & 0.0939 & 0.1472 & 0.1411 & 0.1354 \\
\hline
\end{tabular}

Robust standard errors are shown in parentheses.

${ }^{* * *} p<0.01,{ }^{* *} p<0.05$, and ${ }^{*} p<0.1$

For the full sample, the 2SLS-IV regression model does not change the main finding of the analysis shown in Table 3, but does show a stronger relationship between DFI (DFI, ACCESS, and USAGE) and the level of bank risk-taking by providing a higher coefficient (shown in Table 6). Therefore, the findings indicate the robustness of the PCSEs regression results and suggest that overall the DFI, ACCESS, and USAGE indices have a significant negative impact on the level of bank risk-taking in the sample countries. Most of the control variable results remain unchanged.

Table 7.

DFI and Bank Risk-Taking Using the 2SLS-IV Regression Model (Islamic Banks)

\begin{tabular}{lccccccccc}
\hline & \multicolumn{3}{c}{ DR } & \multicolumn{3}{c}{ LR } & \multicolumn{3}{c}{ PR } \\
\hline & $\mathbf{( 1 )}$ & $\mathbf{( 2 )}$ & $\mathbf{( 3 )}$ & $\mathbf{( 4 )}$ & $\mathbf{( 5 )}$ & $\mathbf{( 6 )}$ & $\mathbf{( 7 )}$ & $\mathbf{( 8 )}$ & $\mathbf{( 9 )}$ \\
\hline \multirow{2}{*}{ DFI } & DFI & ACCESS & USAGE & DFI & ACCESS & USAGE & DFI & ACCESS & USAGE \\
& 0.010 & 0.256 & -1.220 & 0.065 & 0.182 & -1.100 & 0.291 & 0.153 & 0.604 \\
\multirow{3}{*}{ BSIZE } & $(0.587)$ & $(0.518)$ & $(0.939)$ & $(0.583)$ & $(0.531)$ & $(0.881)$ & $(0.604)$ & $(0.563)$ & $(0.932)$ \\
& $-0.411^{* *}$ & $-0.424^{* *}$ & $-0.358^{*}$ & $-0.341^{* *}$ & $-0.354^{* *}$ & $-0.297^{*}$ & $-0.277^{*}$ & $-0.271^{*}$ & $-0.273^{*}$ \\
\multirow{3}{*}{ LSH } & $(0.199)$ & $(0.203)$ & $(0.192)$ & $(0.173)$ & $(0.176)$ & $(0.165)$ & $(0.159)$ & $(0.161)$ & $(0.142)$ \\
& -0.185 & -0.161 & -0.668 & -0.232 & -0.203 & -0.664 & -0.503 & -0.551 & -0.179 \\
\multirow{4}{*}{ DSH } & $(0.611)$ & $(0.601)$ & $(0.796)$ & $(0.636)$ & $(0.628)$ & $(0.795)$ & $(0.815)$ & $(0.796)$ & $(0.951)$ \\
& 0.765 & 0.781 & 0.492 & 0.685 & 0.705 & 0.444 & 0.152 & 0.128 & 0.172 \\
& $(0.971)$ & $(0.981)$ & $(0.999)$ & $(1.008)$ & $(1.015)$ & $(1.058)$ & $(1.304)$ & $(1.301)$ & $(1.250)$ \\
\hline
\end{tabular}


Table 7.

DFI and Bank Risk-Taking Using the 2SLS-IV Regression Model (Islamic Banks) (Continued)

\begin{tabular}{lccccccccc}
\hline & & DR & \multicolumn{9}{c}{ LR } & & \multicolumn{3}{c}{ PR } \\
\hline & $\mathbf{( 1 )}$ & $\mathbf{( 2 )}$ & $\mathbf{( 3 )}$ & $\mathbf{( 4 )}$ & $\mathbf{( 5 )}$ & $\mathbf{( 6 )}$ & $\mathbf{( 7 )}$ & $\mathbf{( 8 )}$ & $\mathbf{( 9 )}$ \\
\hline AG & DFI & ACCESS & USAGE & DFI & ACCESS & USAGE & DFI & ACCESS & USAGE \\
\hline \multirow{2}{*}{ MGTQ } & -0.004 & -0.004 & -0.004 & -0.005 & -0.005 & -0.005 & -0.006 & -0.006 & -0.007 \\
& $(0.003)$ & $(0.003)$ & $(0.003)$ & $(0.003)$ & $(0.003)$ & $(0.003)$ & $(0.005)$ & $(0.005)$ & $(0.005)$ \\
GDPPCG & $-1.560^{*}$ & $-1.602^{*}$ & -1.441 & $-1.405^{*}$ & $-1.447^{*}$ & -1.300 & -2.460 & -2.415 & $-2.578^{*}$ \\
& $(0.892)$ & $(0.898)$ & $(0.950)$ & $(0.827)$ & $(0.832)$ & $(0.887)$ & $(1.511)$ & $(1.486)$ & $(1.509)$ \\
INFL & 0.061 & 0.047 & 0.066 & 0.058 & 0.044 & 0.060 & -0.015 & -0.009 & -0.006 \\
& $(0.076)$ & $(0.075)$ & $(0.069)$ & $(0.069)$ & $(0.068)$ & $(0.063)$ & $(0.063)$ & $(0.064)$ & $(0.059)$ \\
Country-fixed & -0.007 & -0.007 & -0.014 & -0.000 & -0.001 & -0.007 & $-0.038^{*}$ & $-0.037^{*}$ & $-0.033^{*}$ \\
effect & $(0.015)$ & $(0.015)$ & $(0.015)$ & $(0.014)$ & $(0.014)$ & $(0.014)$ & $(0.020)$ & $(0.020)$ & $(0.018)$ \\
Year-fixed & Yes & Yes & Yes & Yes & Yes & Yes & Yes & Yes & Yes \\
effect & Yes & Yes & Yes & Yes & Yes & Yes & Yes & Yes & Yes \\
Bank-fixed & & & & & & & & & \\
effect & Yes & Yes & Yes & Yes & Yes & Yes & Yes & Yes & Yes \\
Obs. & 336 & 336 & 336 & 338 & 338 & 338 & 308 & 308 & 308 \\
$R^{2}$ & 0.2225 & 0.2226 & 0.2385 & 0.2041 & 0.2037 & 0.2179 & 0.2772 & 0.2770 & 0.2804 \\
\hline
\end{tabular}

Robust standard errors are shown in parentheses.

*** $p<0.01,{ }^{* *} p<0.05$, and * $p<0.1$

Table 7 shows the 2SLS-IV regression findings for Islamic banks. The nexus of DFI and bank risk-taking does not change the sign, which confirms the robustness of the previous PCSEs regression results (see Table 4) for Islamic banks. The findings suggest that the nexus of DFI-bank risk-taking for Islamic banks is not significant in comparison to commercial banks overall and/or their counterpart conventional banks. The control variables remain unchanged.

Table 8.

DFI and Bank Risk-Taking Using the 2SLS-IV Regression Model (Conventional Banks)

\begin{tabular}{lccccccccc}
\hline & \multicolumn{3}{c}{ DR } & \multicolumn{3}{c}{ LR } & \multicolumn{3}{c}{ PR } \\
\hline & $\mathbf{( 1 )}$ & $\mathbf{( 2 )}$ & $\mathbf{( 3 )}$ & $\mathbf{( 4 )}$ & $\mathbf{( 5 )}$ & $\mathbf{( 6 )}$ & $\mathbf{( 7 )}$ & $\mathbf{( 8 )}$ & $\mathbf{( 9 )}$ \\
\hline \multirow{2}{*}{ DFI } & DFI & ACCESS & USAGE & DFI & ACCESS & USAGE & DFI & ACCESS & USAGE \\
& $-2.078^{* * * *}$ & $-1.514^{* * *}$ & $-0.636^{* *}$ & $-2.074^{* * *}$ & $-1.506^{* * *}$ & $-0.678^{* *}$ & $-1.712^{* * *}$ & $-1.265^{* * *}$ & -0.475 \\
\multirow{3}{*}{ BSIZE } & $(0.504)$ & $(0.431)$ & $(0.284)$ & $(0.445)$ & $(0.385)$ & $(0.271)$ & $(0.547)$ & $(0.482)$ & $(0.371)$ \\
& -0.064 & -0.076 & $-0.135^{* *}$ & -0.052 & -0.065 & $-0.122^{* *}$ & $-0.200^{* * *}$ & $-0.207^{* * *}$ & $-0.260^{* * *}$ \\
\multirow{2}{*}{ LSH } & $(0.063)$ & $(0.064)$ & $(0.059)$ & $(0.061)$ & $(0.062)$ & $(0.057)$ & $(0.065)$ & $(0.066)$ & $(0.061)$ \\
& $-1.006^{* *}$ & $-1.014^{* *}$ & $-0.868^{*}$ & $-1.037^{* *}$ & $-1.047^{* *}$ & $-0.879^{*}$ & $-1.727^{* * *}$ & $-1.754^{* * *}$ & $-1.583^{* * *}$ \\
\multirow{2}{*}{ DSH } & $(0.488)$ & $(0.488)$ & $(0.502)$ & $(0.464)$ & $(0.463)$ & $(0.478)$ & $(0.485)$ & $(0.481)$ & $(0.500)$ \\
& 0.685 & $0.748^{*}$ & $0.830^{*}$ & 0.675 & 0.742 & $0.810^{*}$ & -0.083 & -0.044 & 0.046 \\
& $(0.435)$ & $(0.436)$ & $(0.453)$ & $(0.451)$ & $(0.453)$ & $(0.469)$ & $(0.329)$ & $(0.333)$ & $(0.342)$ \\
\hline
\end{tabular}


Table 8.

DFI and Bank Risk-Taking Using the 2SLS-IV Regression Model (Conventional Banks) (Continued)

\begin{tabular}{lccccccccc}
\hline & & DR & & \multicolumn{3}{c}{ LR } & \multicolumn{3}{c}{ PR } \\
\hline & $\mathbf{( 1 )}$ & $\mathbf{( 2 )}$ & $\mathbf{( 3 )}$ & $\mathbf{( 4 )}$ & $\mathbf{( 5 )}$ & $\mathbf{( 6 )}$ & $\mathbf{( 7 )}$ & $\mathbf{( 8 )}$ & $\mathbf{9})$ \\
\hline \multirow{2}{*}{ AG } & DFI & ACCESS & USAGE & DFI & ACCESS & USAGE & DFI & ACCESS & USAGE \\
& -0.001 & -0.001 & -0.000 & -0.000 & -0.000 & -0.000 & -0.002 & -0.002 & -0.002 \\
\multirow{4}{*}{ MGTQ } & $(0.001)$ & $(0.001)$ & $(0.002)$ & $(0.001)$ & $(0.001)$ & $(0.001)$ & $(0.002)$ & $(0.002)$ & $(0.002)$ \\
& -0.529 & -0.483 & -0.574 & -0.450 & -0.409 & -0.531 & -0.509 & -0.466 & -0.567 \\
GDPPCG & $(0.654)$ & $(0.655)$ & $(0.666)$ & $(0.648)$ & $(0.650)$ & $(0.667)$ & $(0.701)$ & $(0.698)$ & $(0.713)$ \\
& $0.118^{* *}$ & $0.104^{* *}$ & -0.028 & $0.140^{* * *}$ & $0.126^{* *}$ & -0.007 & 0.060 & 0.050 & -0.064 \\
INFL & $(0.052)$ & $(0.052)$ & $(0.051)$ & $(0.050)$ & $(0.050)$ & $(0.051)$ & $(0.058)$ & $(0.060)$ & $(0.059)$ \\
& 0.028 & 0.034 & -0.009 & 0.029 & $0.035^{*}$ & -0.008 & -0.003 & 0.002 & -0.030 \\
Country-fixed & $(0.022)$ & $(0.022)$ & $(0.023)$ & $(0.020)$ & $(0.021)$ & $(0.021)$ & $(0.023)$ & $(0.022)$ & $(0.023)$ \\
effect & Yes & Yes & Yes & Yes & Yes & Yes & Yes & Yes & Yes \\
Year-fixed effect & Yes & Yes & Yes & Yes & Yes & Yes & Yes & Yes & Yes \\
Bank-fixed effect & Yes & Yes & Yes & Yes & Yes & Yes & Yes & Yes & Yes \\
Obs. & 1236 & 1236 & 1236 & 1240 & 1240 & 1240 & 1137 & 1137 & 1137 \\
$R^{2}$ & 0.0942 & 0.0866 & 0.0815 & 0.0967 & 0.0881 & 0.0819 & 0.1279 & 0.1253 & 0.1212 \\
\hline
\end{tabular}

Robust standard errors are shown in parentheses.

*** $p<0.01, * * p<0.05$, and * $p<0.1$

For the conventional banks, the findings using the 2SLS-IV regression (shown in Table 8) do not change the results of the PCSEs (Table 5), which confirms the robustness of the findings that DFI, ACCESS, and USAGE are negatively and significantly associated with the levels of bank risk-taking. In addition, the control variables remain unaffected.

Up to this point, we have taken static panel regression estimators. We now deploy dynamic panel regression - two-step system generalised method of moments (GMM) to estimate the results and validate our previous findings, as presented in Table 9. The main findings of the dynamic model also validate our results. The insignificant p-value of AR (2) and the Hansen test justify the model validity. Moreover, the smaller number of instruments than number of groups also validates our GMM model specifications in Table 9. Furthermore, we also controlled the traditional financial inclusion index (e.g., ATMs or bank branches) and considered the traditional risk-taking proxy (e.g., the non-performing loans ratio). In all cases, our main results remain unchanged ${ }^{4}$.

4 The results are available upon request. 
Table 9.

Dynamic Panel Two-Step System GMM

\begin{tabular}{lccc}
\hline & & DR & \\
\hline & $\mathbf{( 1 )}$ & $\mathbf{( 2 )}$ & $\mathbf{( 3 )}$ \\
\hline Lagged of DR & DFI & ACCESS & USAGE \\
DFI & $0.249^{* * *}$ & $-0.256^{* * *}$ & $-0.274^{* * *}$ \\
& $(0.038)$ & $(0.038)$ & $(0.038)$ \\
Control variables & $-1.024^{* * *}$ & $-0.620^{* *}$ & $-0.623^{* *}$ \\
Country-fixed effect & $(0.381)$ & $(0.364)$ & $(0.301)$ \\
Year-fixed effect & Yes & Yes & Yes \\
Bank-fixed effect & Yes & Yes & Yes \\
Arellano-Bond test - AR (2) (P-value) & Yes & Yes & Yes \\
Hansen (P-value) & Yes & Yes & Yes \\
Obs. & 0.163 & 0.174 & 0.161 \\
Number of Groups & 0.270 & 0.251 & 0.225 \\
Number of Instruments & 1324 & 1324 & 1324 \\
\hline
\end{tabular}

Robust standard errors are shown in parentheses

*** $p<0.01,{ }^{* *} p<0.05$, and ${ }^{*} p<0.1$

\subsection{Analysis}

Bank risk-taking for both conventional and Islamic banks is important, especially if a dual banking system co-exists in an economy. Therefore, it is necessary to distinguish the extent of such risk-taking in terms of Islamic and conventional banking types. Our findings suggest that the bank types differ significantly based on their risk-taking, with Islamic banks showing a higher degree, but a lower degree of bank stability), compared to conventional banks. Our findings are in line with those of Bitar, Naceur, Ayadi, \& Walker (2020) and Smaoui, Mimouni, Miniaoui, \& Temimi (2020), who found that Islamic banks took more risks than conventional ones.

The negative DFI-bank risk-taking relationship suggests that an increase in the DFI index reduces the level of bank risk-taking. The economic value of the results suggests that DFI has a significant impact on the level of bank risk-taking, which means that it enriches the soundness of individual banks in the sample countries. This indicates that DFI is not only statistically significant, but also economically important, as in strengthening individual banks in the sample, it not only reduces the default risk, leverage risk, and portfolio risk of the individual banks, but also increases their financial mobility, even in the face of crisis. These findings are similar to those of previous studies (e.g., Ahamed \& Mallick, 2019; Banna, 2020b; Banna, Hassan, \& Alam, 2020b; Morgan \& Pontines, 2018), which show that a financial system with inclusive DFS tends to boost banking stability, and that the greater implementation of DFI moderates the excessive risk-taking of particular banks. Moreover, it is also advocated that a digitally inclusive banking sector may help banks to generate a good level of client deposits cheaply, mitigate the financial constraints of SMEs and individuals, and increase financial mobilisation. 
The results also indicate that conventional banks are more sensitive than Islamic ones in terms of the DFI-bank risk-taking nexus in the sample countries. Although overall DFI, ACCESS, and USAGE have a significant negative relationship with the level of bank risk-taking in the full sample and in conventional banks, the insignificant positive relationship between the DFI indices and Islamic bank risktaking can be explained by the fact that these banks are still in an immature phase. Therefore, a large amount of capital, and high operational, communication, and coordination costs are involved in establishing their digitalised financial system, which can put great financial pressure on the banks to increase their risk level in the short-run (Wang et al., 2020). In some of the specifications, our study finds an insignificant nexus of USAGE-bank risk-taking, which suggests that people in the sample countries have sufficient access to digital financial services, as banks and other Fintech companies are trying to provide mobile/internet banking facilities and/or agent outlets services in these areas. However, people in these particular regions are reluctant to use the existing mobile/online services, preferring cash transactions. This finding is supported by a recent study by the World Bank and Mastercard, who found that more than $90 \%$ of financial transactions in developing countries are made with cash (Unnikrishnan, Larson, Pinpradab, \& Brown, 2019). This can be explained by the fact that the practice of digital finance in these regions is still at an early stage, and people lack digital literacy, especially older ones. Therefore, it may take time to make people conversant with technology and digital financial services.

Moreover, the advancement of digital finance products reachable through mobile phones or computers can reduce face-to-face interactions (which is essential in minimising the spread of the Covid-19 virus), but continue to keep people connected to their financial transactions/activities. Consequently, DFI not only aids the banking of unbanked/disadvantaged people, but also benefits banks by allowing them to collect low-priced retail deposits from a massive clientele base (Ahamed \& Mallick, 2019). This can minimise the liquidity problems of banks in times of crisis (e.g., the current Covid-19 pandemic), which ultimately reduces the level of bank risk-taking. Moreover, DFI can also help banks to lend money to their vast clientele, including SMEs and the other vulnerable groups, which eventually improves financial stability by lowering default risk (Morgan \& Pontines, 2018). Therefore, the mobility restrictions put in place to contain the Covid-19 pandemic have encouraged the banking sector to implement DFS at a rapid pace.

Furthermore, DFI helps financial and monetary system regulators to reduce the level of inflation by restricting the circulation of physical cash (Danisman \& Tarazi, 2020). In addition, during any pandemic such as Covid-19, DFI is expected to help governments to reach out to those in the informal sector who have no access to formal bank accounts and to provide quick and secure financial support as an emergency response (Allmen, Khera, Ogawa, \& Sahay, 2020).

Therefore, an inclusive digitalised banking industry ensures sustainable economic growth, which is likely to help maintain financial sustainability in times of economic crisis. 


\section{CONCLUSION AND RECOMMENDATIONS}

\subsection{Conclusion}

This paper has examined the relationship between digital financial inclusion and the levels of bank risk-taking, using a sample of 283 banks from six countries over the period 2011 to 2019. The findings suggest that Islamic banks take more risks than conventional ones. The empirical evidence also indicates that digital financial inclusion is negatively associated with the level of bank risk-taking for the overall commercial banks and conventional banks compared to Islamic banks. Such a strong association suggests that the proper implementation of digital financial inclusion reduces the risk-taking behaviour of banks. Consequently, an inclusive digitalised banking industry will ensure sustainable economic growth, which is likely to help maintain financial sustainability in times of economic crisis such as during the Covid-19 pandemic. Our results have been demonstrated to be robust through various robustness checks.

\subsection{Recommendations}

Based on our findings, policymakers, regulators and standard setters should consider the following implications and policy recommendations. First, the weak nexus of digital financial inclusion and bank risk-taking for Islamic banks indicates that they need to expand their agent networks and digitalise their existing products and services by deploying artificial intelligence and machine learning to appeal to people of all economic classes. In addition, the findings also suggest that people should be provided with proper digital financial literacy by organising campaigns, seminars, and workshops. Next, banks should also introduce services to show how unbanked people can open an account from their home through their electronic devices, as the Covid-19 crisis makes them disinclined to go to bank branch/agent outlets physically to conduct business.

Finally, to minimise technological and internet glitches, banks should upgrade their databases and launch a Quick Response Code-based money withdrawal system, which already prevails in countries such as Singapore and Turkey.

The study has some limitations; for example, we could not consider all dual banking countries in our analysis due to digital financial inclusion data unavailability. Moreover, we did not split our sample based on geographical location, income level, and ownership structure due to the limited number of countries. However, in turn, these limitations create opportunities for future research, in which geographical location, income level, and ownership structure could be taken into consideration.

\section{ACKNOWLEDGEMENTS}

The authors would like to thank the anonymous referees, the managing editor Dr. Ascarya, Prof. Dr. Mansor Ibrahim, and Prof. Dr. M. Kabir Hassan for their critical reviews and valuable comments. The research was partially funded by the Faculty of Business and Accountancy, Universiti Malaya (Grant number: GPF043A-2020). The usual disclaimers apply. 


\section{REFERENCES}

Agoraki, M.-E. K., Delis, M. D., \& Pasiouras, F. (2011). Regulations, competition and bank risk-taking in transition countries. Journal of Financial Stability, 7(1), 38-48. doi:https://doi.org/10.1016/j.jfs.2009.08.002.

Ahamed, M. M., \& Mallick, S. K. (2019). Is financial inclusion good for bank stability? International evidence. Journal of Economic Behavior E Organization, 157(C), 403-427.

Ahmed, H., Mohieldin, M., Verbeek, J., \& Aboulmagd, F. (2015). On the sustainable development goals and the role of Islamic finance. Policy Research Working Paper (June 11 ,2015). World Bank Group.

Al-Smadi, M. O. (2018). The role of financial inclusion in financial stability: Lesson from Jordan. Banks and Bank Systems, 13(4), 31.

Ale, B. (2009). Risk: an introduction: The concepts of risk, danger and chance. New York: Routledge.

Alfadli, A., \& Rjoub, H. (2019). The impacts of bank-specific, industry-specific and macroeconomic variables on commercial bank financial performance: evidence from the Gulf cooperation council countries. Applied Economics Letters, 27(15), 1-5.

Allen, F., Carletti, E., Cull, R., Qian, J. Q., Senbet, L., \& Valenzuela, P. (2014). The African financial development and financial inclusion gaps. Journal of African Economies, 23(5), 614-642.

Allmen, U. E., Khera, P., Ogawa, S., \& Sahay, R. (2020). Digital Financial Inclusion in the Times of COVID-19. Retrieved from https://blogs.imf.org/2020/07/01/ digital-financial-inclusion-in-the-times-of-covid-19/.

Altunbas, Y., Carbo, S., Gardener, E. P., \& Molyneux, P. (2007). Examining the relationships between capital, risk and efficiency in European banking. European Financial Management, 13(1), 49-70.

Anderson, R. C., \& Fraser, D. R. (2000). Corporate control, bank risk taking, and the health of the banking industry. Journal of Banking \& Finance, 24(8), 13831398.

Anginer, D., Demirguc-Kunt, A., Huizinga, H., \& Ma, K. (2013). How does corporate governance affect bank capitalization strategies?. Policy Research Working Paper No.6636. Washington DC: World Bank.

Ashraf, B. N. (2017). Political institutions and bank risk-taking behavior. Journal of Financial Stability, 29, 13-35.

Ashraf, B. N., Zheng, C., \& Arshad, S. (2016). Effects of national culture on bank risk-taking behavior. Research in International Business E Finance, 37, 309-326.

Atkeson, A. (2020). What will be the economic impact of covid-19 in the us? rough estimates of disease scenarios (0898-2937). Retrieved from National Bureau of Economic Research: https://www.nber.org/papers/w26867

Banna, H. (2020a). Minimizing the economic impact of Coronavirus in Bangladesh. The Business Standard. Retrieved from https://tbsnews.net/thoughts/ minimising-economic-impact-coronavirus-bangladesh-56449

Banna, H. (2020b). The role of digital financial inclusion on promoting sustainable economic growth through banking stability: Evidence from Bangladesh. Development Review, 29, 19-36. 
Banna, H., \& Alam, M. R. (2020). Islamic banking efficiency and inclusive sustainable growth: The role of financial inclusion. Journal of Islamic Monetary Economics and Finance, 6(1), 213-242.

Banna, H., Alam, M. R., Ahmad, R., \& Sari, N. M. (2020a). Does financial inclusion drive the Islamic banking efficiency? A post-financial crisis analysis. The Singapore Economic Review. doi:10.1142/s0217590819420050.

Banna, H., Hassan, M. K., \& Alam, M. R. (2020b). Digital financial inclusion, islamic banking stability and sustainable economic growth. In M. Saraç \& M. K. Hassan (Eds.), Islamic Perspective for Sustainable Financial System (pp. 131152). Istanbul: Istanbul University Press.

Beck, N., \& Katz, J. N. (1995). What to do (and not to do) with time-series crosssection data. American Political Science Review, 89(3), 634-647.

Beck, T., Demirguc-Kunt, A., \& Martínez-Pería, M. S. (2007). Reaching out: Access to and use of banking services across countries. Journal of Financial Economics, 85(1), 234-266.

Beck, T., Lin, C., \& Ma, Y. (2014). Why do firms evade taxes? The role of information sharing and financial sector outreach. The Journal of Finance, 69(2), 763-817.

Beltratti, A., \& Stulz, R. M. (2012). The credit crisis around the globe: Why did some banks perform better? Journal of Financial Economics, 105(1), 1-17.

Berger, A. N., \& DeYoung, R. (1997). Problem loans and cost efficiency in commercial banks. Journal of Banking and Finance, 21(6), 849-870.

Bitar, M., Naceur, S. B., Ayadi, R., \& Walker, T. (2020). Basel compliance and financial stability: Evidence from Islamic banks. Journal of Financial Services Research. doi:10.1007/s10693-020-00337-6.

Black, L. K., \& Hazelwood, L. N. (2013). The effect of TARP on bank risk-taking. Journal of Financial Stability, 9(4), 790-803.

CGAP (2014) Financial Inclusion. Retrieved from http://www.cgap.org/topics/ financial-inclusion.

CGAP (2015) What is Digital Financial Inclusion and Why Does it Matter? . Retrieved from http://www.cgap.org/blog/what-digital-financial-inclusionand-why-does-it-matter.

Cubillas, E., \& González, F. (2014). Financial liberalization and bank risk-taking: International evidence. Journal of Financial Stability, 11, 32-48.

Dahir Ahmed, M., Mahat Fauziah, B., \& Ali Noor Azman, B. (2018). Funding liquidity risk and bank risk-taking in BRICS countries: An application of system GMM approach. International Journal of Emerging Markets, 13(1), 231248.

Danisman, G. O., \& Tarazi, A. (2020). Financial inclusion and bank stability: Evidence from Europe. The European Journal of Finance, 26(18), 1-14. doi:10.108 0/1351847X.2020.1782958.

Delis, M. D., \& Kouretas, G. P. (2011). Interest rates and bank risk-taking. Journal of Banking \& Finance, 35(4), 840-855.

Dell' Ariccia, G., \& Marquez, R. (2006). Lending booms and lending standards. The Journal of Finance, 61(5), 2511-2546.

Demirguc-Kunt, A., \& Klapper, L. (2012). Measuring financial inclusion: The global findex database. Policy Research Working Paper (April ,2012). World Bank Group.

Ernst \& Young (2013). World Islamic Banking Competitiveness Report 2013-14. In: Ernst \& Young Dubai. 
Fiordelisi, F., Marques-Ibanez, D., \& Molyneux, P. (2011). Efficiency and risk in European banking. Journal of Banking \& Finance, 35(5), 1315-1326.

Flannery, M. J. (2009). Market discipline in bank supervision. In A. N. Berger, P. Molyneux, J. O. S. Wilson (Eds.), The Oxford Handbook of Banking (1 ${ }^{\text {st }}$ ed.). New York: Oxford University Press.

García-Kuhnert, Y., Marchica, M.-T., \& Mura, R. (2015). Shareholder diversification and bank risk-taking. Journal of Financial Intermediation, 24(4), 602-635.

Han, R., \& Melecky, M. (2013). Financial inclusion for financial stability: Access to bank deposits and the growth of deposits in the global financial crisis. Policy Research Working Paper (August ,2013). World Bank Group.

Hancock, M. (2013). Islamic finance in 2013: Beyond the growth. The Banker, (March $1,2013)$.

Houston, J. F., Lin, C., Lin, P., \& Ma, Y. (2010). Creditor rights, information sharing, and bank risk taking. Journal of Financial Economics, 96(3), 485-512. doi:https:// doi.org/10.1016/j.jfineco.2010.02.008.

Hughes, J. P., \& Mester, L. J. (2008). Efficiency in banking: Theory, practice, and evidence. Working Paper, No. 2008-01. Rutgers University, Department of Economics, New Brunswick, NJ.

Hughes, J. P., Mester, L. J., \& Moon, C.-G. (2001). Are scale economies in banking elusive or illusive?: Evidence obtained by incorporating capital structure and risk-taking into models of bank production. Journal of Banking Finance, 25(12), 2169-2208.

Kacperczyk, M., \& Schnabl, P. (2013). How safe are money market funds? The Quarterly Journal of Economics, 128(3), 1073-1122.

Kammoun, S., Loukil, S., \& Loukil, Y. B. R. (2020). The Impact of FinTech on economic performance and financial stability in MENA zone. In N. Naifar (Ed.), Impact of Financial Technology (FinTech) on Islamic Finance and Financial Stability (pp. 253-277). Pennsylvania: IGI Global.

Keeley, M. C. (1990). Deposit insurance, risk, and market power in banking. The American Economic Review, 80(5), 1183-1200.

Khan, M. S., Scheule, H., \& Wu, E. (2017). Funding liquidity and bank risk taking. Journal of Banking \& Finance, 82, 203-216. doi:https://doi.org/10.1016/j. jbankfin.2016.09.005.

Kim, H., Batten, J. A., \& Ryu, D. (2020). Financial crisis, bank diversification, and financial stability: OECD countries. International Review of Economics \& Finance, 65, 94-104.

Klapper, L. (2017). How digital payments can benefit entrepreneurs. IZA World of Labor.

Koetter, M. (2008). The stability of bank efficiency rankings when risk preferences and objectives are different. European Journal of Finance, 14(2), 115-135.

Laeven, L., \& Levine, R. (2009). Bank governance, regulation and risk taking. Journal of Financial Economics, 93(2), 259-275. doi:https://doi.org/10.1016/j. jfineco.2008.09.003.

Landstrom, H. (2007). Pioneers in entrepreneurship and small business research (Vol. 8). Boston: Springer Science \& Business Media.

Lepetit, L., Nys, E., Rous, P., \& Tarazi, A. (2008). Bank income structure and risk: An empirical analysis of European banks. Journal of Banking $\mathcal{E}$ Finance, 32(8), 1452-1467. doi:https://doi.org/10.1016/j.jbankfin.2007.12.002. 
Li, L., Strahan, P. E., \& Zhang, S. (2020). Banks as Lenders of First Resort: Evidence from the COVID-19 Crisis. The Review of Corporate Finance Studies, 9(3), 472-500. doi:10.1093/rcfs/cfaa009.

Malikov, E., Restrepo-Tobon, D., \& Kumbhakar, S. (2015). Estimation of banking technology under credit uncertainty. Empirical Economics, 49(1), 185-211.

Manyika, J., Lund, S., Singer, M., White, O., \& Berry, C. (2016). Digital finance for all: Powering inclusive growth in emerging economies. McKinsey Global Institute, 1-15. Digital Financial Services.

Morgan, P. J., \& Pontines, V. (2018). Financial stability and financial inclusion: The case of SME lending. The Singapore Economic Review, 63(01), 111-124.

Naceur, S. B., \& Omran, M. (2011). The effects of bank regulations, competition, and financial reforms on banks' performance. Emerging Markets Review, 12(1), $1-20$.

Ozili, P. K. (2018). Impact of digital finance on financial inclusion and stability. Borsa Istanbul Review, 18(4), 329-340.

Sarmiento, M., \& Galán, J. E. (2017). The influence of risk-taking on bank efficiency: Evidence from Colombia. Emerging Markets Review, 32, 52-73.

Shleifer, A., \& Vishny, R. (2010). Unstable banking. Journal of Financial Economics, 97(3), 306-318.

Smaoui, H., Mimouni, K., Miniaoui, H., \& Temimi, A. (2020). Funding liquidity risk and banks' risk-taking: Evidence from Islamic and conventional banks. Pacific-Basin Finance Journal, 64, 101436. doi:https://doi.org/10.1016/j. pacfin.2020.101436.

Trimpop, R. M. (1994). The psychology of risk taking behavior. Amsterdam: Elsevier.

United Nations. (2015). Financial Inclusion. Retrieved from https://www. un.org/development/desa/socialperspectiveondevelopment/issues/financialinclusion.html\#: :text=Financial \%20access $\% 20$ means $\% 20$ access $\% 20$ to,to $\% 20$ an\%20increase\%20financial\%20capability.

Unnikrishnan, S., Larson, J., Pinpradab, B., \& Brown, R. (2019). How Mobile Money Agents Can Expand Financial Inclusion. Retrieved from https://www. bcg.com/publications/2019/how-mobile-money-agents-can-expand-financialinclusion.

Van, L. T.-H., Nguyen, N. T., \& Vo, D. H. (2020). Financial inclusion and stability in the Asian region using bank-level data. Borsa Istanbul Review, 21(1), 36-43.

Wagner, W. (2010). Loan market competition and bank risk-taking. Journal of Financial Services Research, 37(1), 71-81.

Wang, R., Liu, J., \& Luo, H. (2020). Fintech development and bank risk taking in China. The European Journal of Finance, 27(4-5), 1-22. doi:10.1080/135184 7X.2020.1805782

Wójcik, D., \& Ioannou, S. (2020). Covid-19 and finance: Market developments so far and potential impacts on the financial sector and centres. Tijdschrift voor economische en sociale geografie, 111(3), 387-400. doi:10.1111/tesg.12434

World Bank. (2015). Digital Financial Inclusion. Retrieved from https://www. worldbank.org/en/topic/financialinclusion/publication/digital-financialinclusion.

Yates, J. (1992). Risk-taking behavior. Washington: John Wiley \& Sons. 
This page is intentionally left blank 